\title{
Not Only Flint: Levallois on Quartzite and Limestone at Abrigo de la Quebrada (Valencia, Spain): Implications for Neandertal Behavior
}

\author{
A LEIX EIXEA, Department of Prehistory and Archaeology, University of Valencia, \\ c/ Blasco Ibáñez, 28, 46010 Valencia (Spain).Email: alejo.eixea@uv.es \\ VALENTIN VILLAVERDE, Department of Prehistory \\ and Archaeology, University of Valencia \\ JOÃO ZILHÃO, Department of Prehistory, Ancient History and \\ Archaeology, ICREA/University of Barcelona
}

\begin{abstract}
This paper investigates the application of the Levallois technique to the knapping of nonflint raw materials (limestone and quartzite) in the upper levels of the Abrigo de la Quebrada rockshelter (Chelva, Valencia, Spain). Besides highlighting the significant flexibility that characterized Neandertal behavior, such an application is of singular interest because goodquality flint-lacking fissures and impurities and presenting a compact and homogeneous texture-is abundant in the site's immediate vicinity. In other assemblages, the scarcity or poor quality of flint often suffices to explain the recourse to alternatives, but in these Quebrada levels raw material choice must be primarily determined by other factors. Based on the dimensions of the different blank types, the percentage of Levallois blanks that were retouched into formal tools, and the presence of use-wear damage, combined with inferences derived from the study of the faunal remains, the hearths, and the spatial distribution of finds, it is proposed that such factors concern the length and function of the occupations and the wider systems of settlement, subsistence, and mobility of which such occupations were a part.
\end{abstract}

Key words: lithic technology, Levallois, limestone, quartzite, Middle Paleolithic, Neandertal behavior, Iberian Peninsula

In the specialized literature, the Levallois technique is often almost exclusively linked to flint (Boëda 1994; Locht 2003; Tuffreau 1987). Likewise, the lack of quality lithic materials in the immediate procurement sources is often associated with the expedient nature of some Middle Paleolithic industries (Geneste 1997; Moncel et al. 2008; Slimak 2003). The underlying idea is that the technical constraints of 
the Levallois method necessitate quality raw materials, in contrast to the discoid method and other techniques for obtaining thick blanks. This seems to be supported by evidence from a large number of French Middle Paleolithic sites, but exceptions have been found in lithic assemblages from the Iberian Peninsula, as well as at some sites in Italy, Belgium, France, and North Africa.

Challenging the view that the Middle Paleolithic use of raw materials other than flint was expedient, a number of Iberian assemblages feature the application of the Levallois method to quartzite, limestone, or mudstone, namely in the Cantabrian region (Arrizabalaga and Rios 2012; Maíllo 2005a; Rios 2010). In a few cases, the exploitation of these raw materials to obtain Levallois microlithic pieces has also been noted (Mora et al. 2004; Villaverde et al. 2012). Lack of flint in the immediate raw-material procurement territory is the reason most often invoked to explain the recourse to such rocks.

Since the lithic materials used in the Middle Paleolithic are mostly obtained from immediate sources (Geneste 1988), it is to be expected that differences between sites will be strongly determined by issues of availability and suitability for knapping. For this reason, it is important to assess the extent to which quartzite and limestone are used for Levallois lithic production in sites where a variety of raw materials were exploited. When different lithic materials, including flint, are easily accessible nearby, as is the case at Quebrada, reasons other than the economics of availability, procurement, and transport must be sought in order to explain the choice of the rocks to which the Levallois technique was applied. For instance, the relative quality of the different materials must be considered because a simple comparison of flint versus quartzite and limestone would not capture the variation in suitability for knapping observed within each of these broad raw-material categories. An additional factor to be considered is that the choice of raw material could have been influenced by how long implements were to be used. Following Boëda (1991), one also needs to bear in mind that tradition can sometimes carry more weight than economy when it comes to making such choices, but this factor is difficult to assess.

Even though Quebrada is not the first instance in which the application of the Levallois method to significant amounts of quartzite and limestone is reported, it is of particular interest because both the Levallois and the discoid methods are applied to all three of them. Elsewhere, the application of the Levallois method on quartzite correlates with this rock being the primary raw material, representing $80 \%$ or more of the assemblage. The link between availability and choice is well apparent in such cases, but Quebrada is distinct because there is no scarcity of flint or fine-grained limestone in its surroundings. At this site, therefore, a behavioral flexibility whose explanation goes beyond mere adaptation to immediate availability must be implicated. In the specialized literature, mobility patterns and length of occupation are often invoked alongside availability and suitability as potential explanations, and the extent to which such factors may have been in operation at Quebrada needs to be assessed. This is the primary aim of the study presented here. 


\section{THE SITE}

Abrigo de la Quebrada (no. 9 on Figure 1) is a rockshelter situated near Chelva, some $65 \mathrm{~km}$ northwest of the city of Valencia. The area's main geographic features are the Tuéjar-Chelva and Turia rivers, along with the rather steep mountains belonging to the Javalambre and Sierra de Utiel massifs, which are part of the Iberian system. The site is on the left bank of the Barranco de Ahillas (Figure 2). Defined on the basis of the present-day position of the overhang and the extent of the horizontal platform it protects, the rockshelter is $38 \mathrm{~m}$ long and between 2 and $9 \mathrm{~m}$ deep. The floor surface is rather flat, with a slight dip from north to south. Since it faces northwest and is inset in a very narrow ravine with steep slopes, the rockshelter receives little direct sunlight.

The excavations, still in progress, have revealed eight archaeological levels. Human occupation is found in levels II-V, VII, and VIII and was most intensive in levels III, IV, and V (Eixea et al. 2011-2012). The following AMS dates on charcoal have been obtained: for level III, 40,500 \pm 530 вP (Beta-244003), on a sample of Pinus nigra recovered in spit 5 of square B5; for level IV, 43,930 \pm 750 вр (Beta244002), on an ABA-treated sample of Pinus cf. pinaster from a combustion feature in spit 6 of square A4, and $>50.8 \mathrm{ka}$ BP (OxA-24855), on an ABOx-ed sample of Pinus cf. nigra (Eixea et al. 2011-2012; Villaverde et al. 2008). The last result indicates that the finite Beta results are minimum ages only and that the upper part of the sequence minimally dates to the early part of MIS 3; the lower levels (VII-VIII) probably date back to MIS 5 .

In levels II and III, raw-material procurement was carried out within a radius of $5 \mathrm{~km}$ around the site, even though some flint from sources more than $100 \mathrm{~km}$ away is also present (Eixea et al. 2011, 2014) (Figure 2). One of the main characteristics of these levels is the production of small flakes in the final stages of core reduction (there is almost no evidence of multiplication of operational chains-i.e., of the routine recycling of flakes as cores for the extraction of smaller products; Bourguignon et al. 2004; Geneste and Plisson 1996; Rios et al. 2015a). The proximity of raw-material sources indicates that exhaustion cannot explain the small size of some blanks, which were never retouched and were probably made for immediate utilization of their sharp, unmodified edges. Use wear has been documented at the macroscopic level in 40 items from level II, 85 from level III, and 92 from level IV (i.e., in all of the levels studied here); the preliminary results for a sample of 22 small flakes analyzed at the microscopic level indicate that a third of them were used mostly in cutting activities, including butchery (Villaverde et al. 2012).

\section{MATERIALS AND METHODS}

Three levels of the Quebrada sequence-levels II, III, and IV-are reported here. Level I, whose assemblage exhibits the effects of livestock trampling, is not considered. 


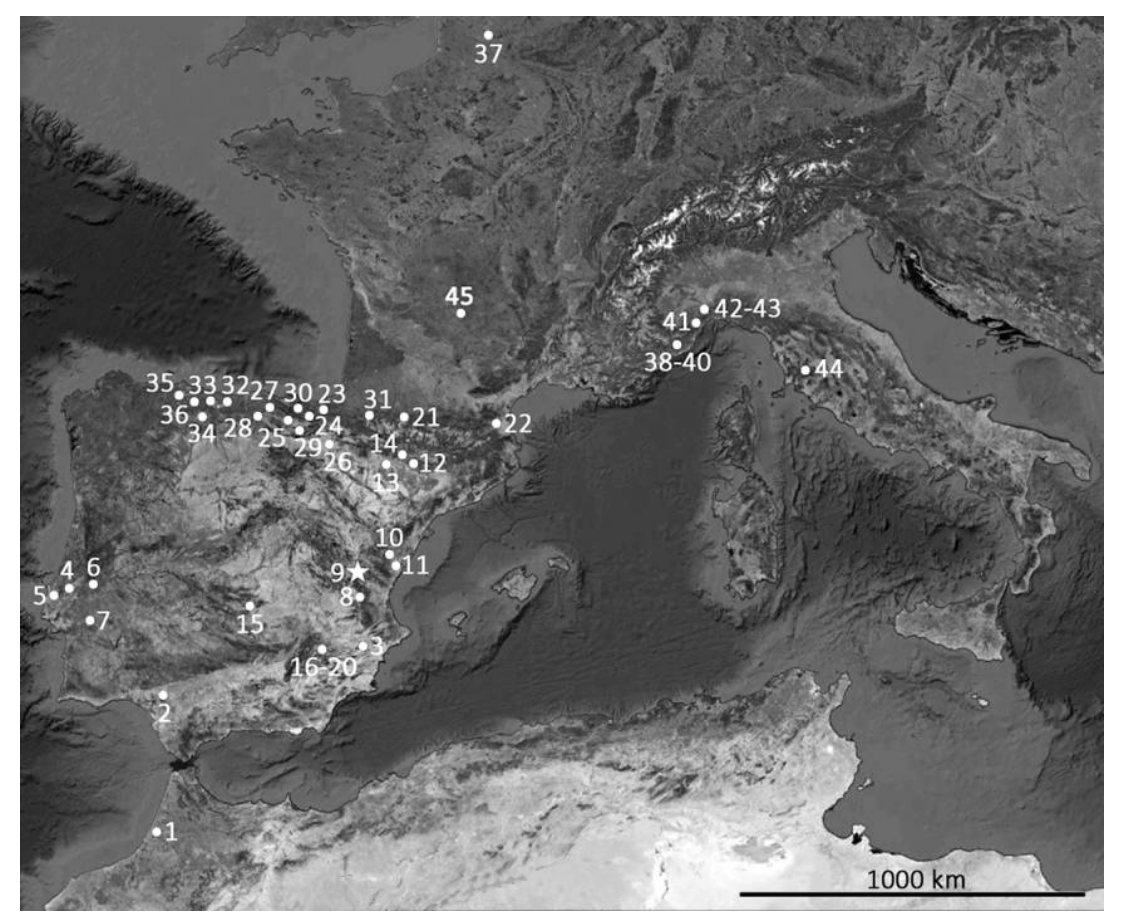

Figure 1. Location of the sites mentioned in the text.
1. Contrebandiers
25. Axlor
2. Tarazona III
26. Peña Miel
3. Cueva Antón
27. Cueva Morín
4. Oliveira
28. El Castillo
5. Columbeira
29. Urrunaga
6. Vilas Ruivas
30. Arlanpe
7. Escoural
31. Gatzarria
8. San Luís
32. La Flecha
9. Abrigo de la Quebrada
33. El Esquilleu
10. Árguinas-Majadal
34. El Habario
11. Hoya Albaida-Titonares
35. La Viña
13. Estret de Tragó
14. Cova Gran
15. Porzuna
16-20. Canalizo del Rayo, Laguna del
Polope, Cerro de la Cantera, Calderón del
Moro, and Rambla del Talave
21. Noisetier
22. Tournal
23. Amalda
24. Lezetxiki
36. Cueva de la Güelga
37. Scladina
38-40. Riparo Mochi, Grotta del Principe, and Madonna dell'Arma (and nearby San Francesco, which is not numbered)
41. Grotta del Colombo
42-43. Arma delle Manie and Grotta delle Fate
44. La Rosa
45. La Borde 


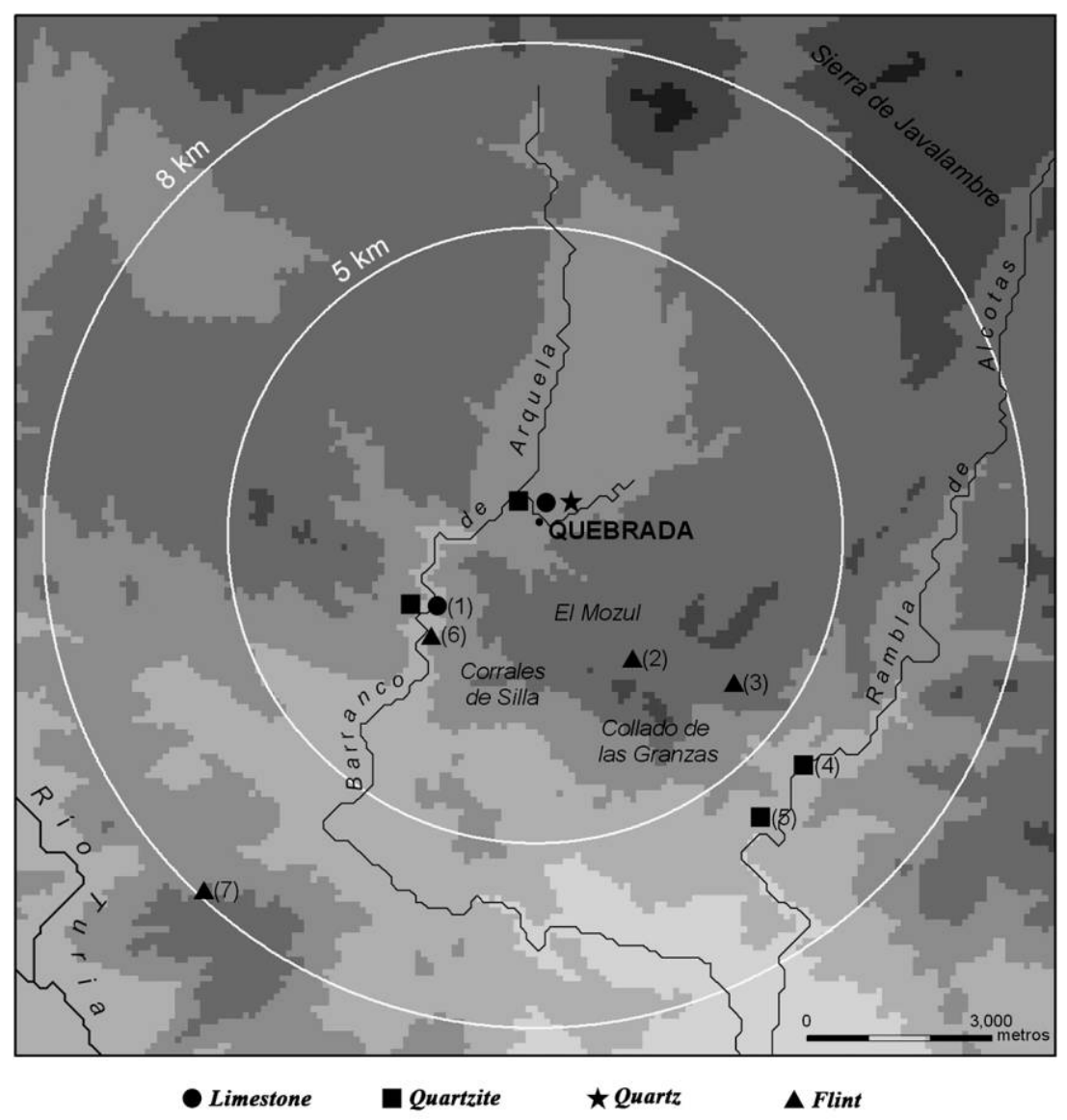

Figure 2. Sources and procurement areas of the local Domeño flint and other lithic materials used at Quebrada.

Four different lithological types have so far been identified among the Quebrada raw materials: flint, limestone, quartzite, and quartz. The local flint, known as the Domeño type, is the most abundant. It occurs in Middle Jurassic formations and is well-suited for knapping-fine-grained and shiny, it features a smooth surface, is without inclusions, opaque, and has a microcrystalline texture. The geological stratum where it was first identified occurs on the hillsides above the Turia River, 5 to $8 \mathrm{~km}$ from the site. The allochthonous flints have been classified into four subgroups (Types 1, 2, 3, and 4) and constitute good-quality raw materials whose macroscopic attributes differ from the Domeño type and match sources located $>100 \mathrm{~km}$ away (for details, see Eixea et al. 2011; Roldán et al. 2015). The limestone selected for knapping is micritic, fine-grained, with smooth surfaces and a microcrystalline structure, and it comes in two subtypes: one was obtained from seams 
Table 1. Lithic artifact counts per raw material, excluding chippage (anything $<1 \mathrm{~cm}$ in maximum dimension) and unclassifiable material (débris, chunks, and thermoclasts-i.e., all formless items regardless of size)

\begin{tabular}{lccccr}
\hline & Flint & Limestone & Quartzite & Quartz & Total \\
\hline Level II & 499 & 85 & 80 & 0 & 664 \\
Level III & 542 & 117 & 111 & 4 & 774 \\
Level IV & 726 & 268 & 319 & 1 & 1314 \\
Total & 1767 & 470 & 510 & 5 & 2752 \\
\hline
\end{tabular}

interstratified in the local bedrock and the other was large $(20-25 \mathrm{~cm})$, riverbedcollected cobbles derived from the erosion of such seams. A single outcrop in the canyon of the Alcotas, $8-10 \mathrm{~km}$ from the site, supplied the quartzite, which can also be found downstream from the canyon as $5-30 \mathrm{~cm}$ cobbles of uneven quality distributed by fluvial erosion across this hydrographic basin.

We have counted as Levallois all blanks of regular morphology with a longitudinal symmetry axis, sharp edges, a dorsal face showing several scars related to the preparation of the knapping surface (lateral and distal convexities), and faceted striking platforms (Boëda 1994; Boëda et al. 1990); the secondary blanks whose dorsal side also showed one or more invasive scars interpreted as extractions from previous phases of knapping (recurrent method) have also been included. All thick, often overshot and/or cortical blanks with unfaceted platforms and asymmetric cross-sections resulting from the kind of centripetal or chordal knapping that typically produces elements of pseudolevallois morphology have been counted as discoid (Boëda 1993; Mourre 2003; Slimak 2003).

Level II yielded 664 pieces. Flint is the predominant raw material (75.2\%), followed by limestone (12.8\%) and quartzite (12\%) (Table 1). As for technique, the Levallois method, in its different varieties, prevails (57.63\%); the discoid method (39.24\%) comes second (Table 2).

Of the 774 lithics from level III, the majority are flint (70.1\%), followed by limestone $(15.1 \%)$ and quartzite (14.3\%). Quartz is hardly represented (0.5\%). Regarding

Table 2. Number of blanks by knapping technique (includes both complete and incomplete flakes, blades, cores, and tools)

\begin{tabular}{lcccc}
\hline & $\begin{array}{c}\text { Levallois } \\
\text { (sensu lato) }\end{array}$ & Discoid & Other & Total \\
\hline Level II & 332 & 226 & 106 & 664 \\
Level III & 444 & 156 & 174 & 774 \\
Level IV & 369 & 417 & 528 & 1314 \\
Total & 1145 & 799 & 808 & 2752 \\
\hline
\end{tabular}


technique, Levallois represents $73.27 \%$ of the classified material; $25.74 \%$ is discoid, a rather more significant difference in relative frequency than observed in level II. A Levallois limestone core of the recurrent centripetal type, reused as a scraper, was found in this level.

Finally, level IV yielded 1314 pieces. Flint continues to be the predominant raw material (55.25\%), but less so than in the overlying levels. Quartzite $(24.20 \%)$ is here more frequent than limestone (20.49\%), while quartz continues to be marginal $(0.06 \%)$. As for technique, there is a change in relation to levels II and III, the discoid $(52.52 \%)$ being slightly more frequent than the Levallois $(46.47 \%)$ method. A recurrent centripetal Levallois quartzite core reused as a scraper was found in this level.

\section{RESULTS}

In all three levels flint is the predominant raw material among Levallois products. It represents $64 \%$ of all the lithics but, on average, stands for some $80 \%$ of all Levallois blanks. Generally speaking, use of flint increases from bottom to top, but the differences do not have statistical significance (chi-square $p$ value $=1.25$ ): Levallois blanks on quartzite and limestone are $21.4 \%$ in level IV, $19.37 \%$ in level III, and $15 \%$ in level II (Table 3). Therefore, enough quartzite and limestone pieces exist in the three levels for the Levallois reduction of these raw materials to be considered significant despite the local abundance and predominant use of flint.

Regarding morpho-technical criteria, 30 quartzite and 20 limestone blanks are available for study in level II (Table 4). The recurrent centripetal flake variety clearly dominates (76.70\%) among quartzite, followed by the preferential variety (13.30\%). The recurrent unidirectional (3.30\%) and bidirectional (6.70\%) varieties are in a minority in all three levels. In general, most blanks are wide and short (Eixea 2012; Villaverde et al. 2008, 2012).

As for the typology of the 11 retouched quartzite items in level II (36\%), most are scrapers (three simple, one of which is on a Levallois preferential flake, and two double). There also are four pieces with use wear and two Levallois preferential flakes (Figure 3). All the limestone materials are Levallois recurrent centripetal, and only one-a naturally backed knife made on an overshot flake-has been classified typologically.

There are 86 limestone and quartzite blanks in level III. Fifty are quartzite, of which, similarly to level II, $82 \%$ are recurrent centripetal, $14 \%$ preferential, and only $4 \%$ unidirectional recurrent. Nineteen quartzite pieces $(38 \%)$ were classified typologically: eight Levallois preferential flakes, four scrapers (two simple and two transversal), and four pieces with notched or denticulated edges. There are also two Levallois points and a Mousterian point, all three exhibiting distal impact fractures. On limestone, the centripetal recurrent is the predominant Levallois modality, with $83.3 \%$ of the blanks, followed by preferential, with $11.1 \%$, and unidirectional recurrent, with $5.6 \%$. The eight retouched pieces $(22.2 \%)$ are three Levallois preferential 


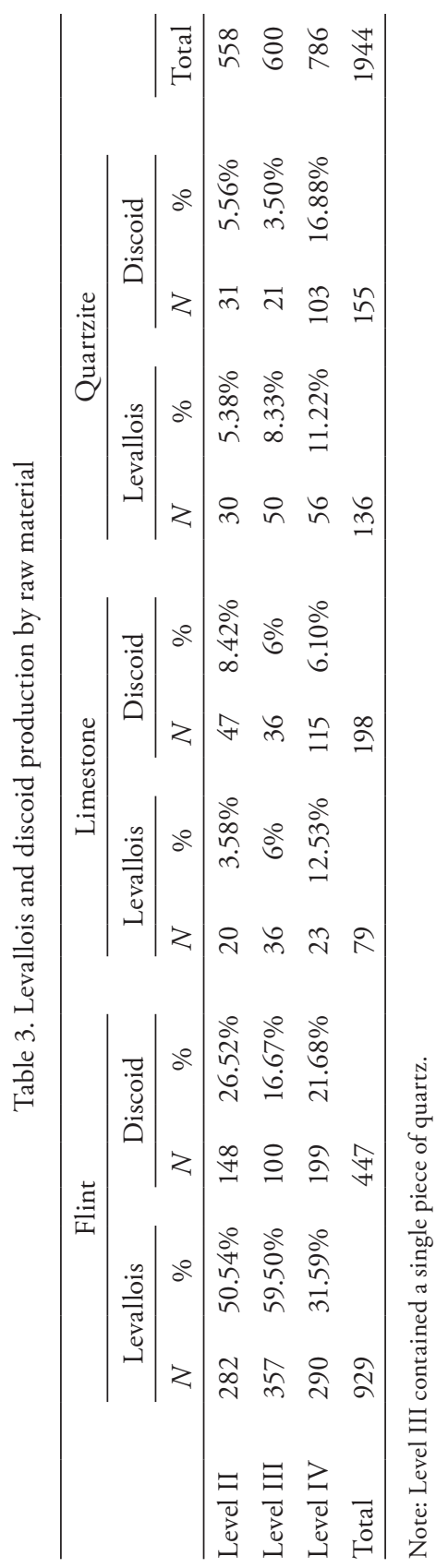

This content downloaded from 194.117.002.103 on January 25, 2018 03:31:56 AM All use subject to University of Chicago Press Terms and Conditions (http://www.journals.uchicago.edu/t-and-c). 
Table 4. Levallois production modalities by level and raw material

\begin{tabular}{llrrccr}
\hline & & LP & LRC & LRU & LRB & Total \\
\hline Level II & Flint & 32 & 238 & 8 & 4 & 282 \\
& Quartzite & 4 & 23 & 1 & 2 & 30 \\
\multirow{3}{*}{ Level III } & Limestone & 0 & 20 & 0 & 0 & 20 \\
& Flint & 34 & 308 & 8 & 7 & 357 \\
& Quartzite & 7 & 41 & 2 & 0 & 50 \\
Level IV & Limestone & 4 & 30 & 2 & 0 & 36 \\
& Flint & 59 & 224 & 1 & 6 & 290 \\
& Quartzite & 10 & 44 & 0 & 2 & 56 \\
\hline
\end{tabular}

LP: Levallois preferential; LRC: Levallois recurrent centripetal; LRU: Levallois recurrent unidirectional; LRB: Levallois recurrent bidirectional

flakes; two denticulates; an atypical backed knife; a wide and short, distally fractured Levallois point; and a flake with use wear (Figure 4).

Among the quartzite Levallois blanks from level IV, the centripetal recurrent modality predominates (78.60\%), followed by the preferential $(17.90 \%)$; the bidirectional recurrent variety is represented by only $3.50 \%$ of the blanks. The typologically classified pieces represent $30 \%$ of the total: seven are Levallois preferential flakes with use wear, five are scrapers (including three made on preferential flakes), three are pieces with use wear, and two are Mousterian points. As for limestone, 23 Levallois preferential pieces have been identified, of which $91.3 \%$ are of the centripetal recurrent modality and the remaining $8.7 \%$ are preferential. We have classified them as two Levallois preferential flakes, a Levallois point, a convex transversal scraper, and an arched-back point resembling Uluzzian and counted in the miscellaneous group (Figure 5).

These data show significant use of the Levallois recurrent centripetal and preferential methods in the quartzite and limestone products from the levels of Quebrada studied here. Preferential flakes are $12.5 \%$ of all Levallois flakes, and the significance of this modality (especially for quartzite, with such blanks representing $15.1 \%$, as opposed to only $6.6 \%$ for limestone) is confirmed by the number of preferential Levallois cores in the three levels combined-eight in total, representing $17.4 \%$ of all Levallois cores. Initially, all Levallois production may have been preferential and only in later stages of core reduction did it become recurrent, as suggested by the small dimensions of the last extractions observed on some cores that were intensively reduced (Villaverde et al. 2012). This may have been the case especially for limestone, for which the centripetal recurrent modality is represented by $91 \%$ of all blanks (as opposed to $80 \%$ for quartzite). Unidirectional and bidirectional Levallois products in these raw materials are few or nonexistent (see Table 4). 

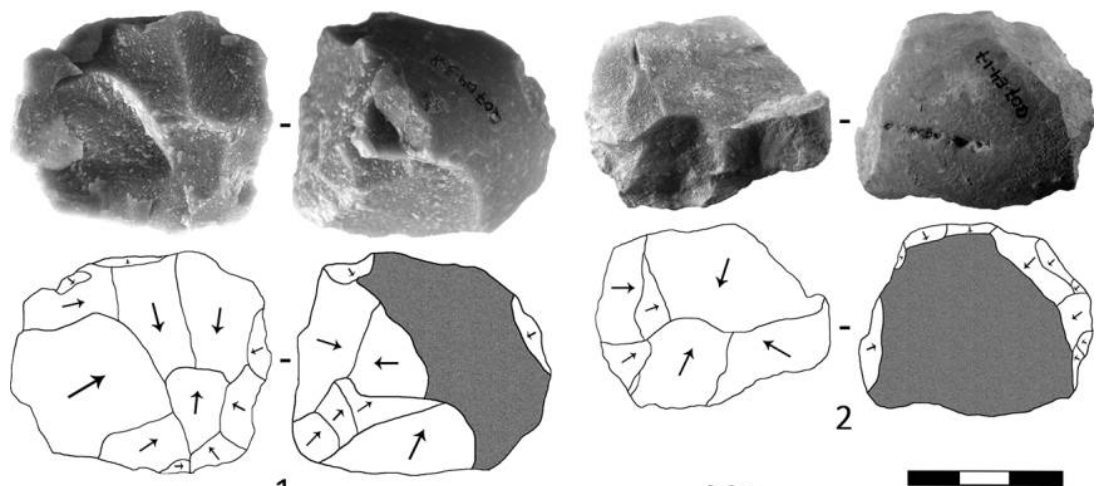

1

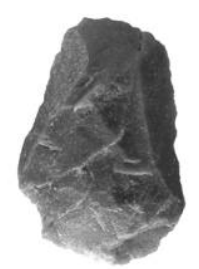

4

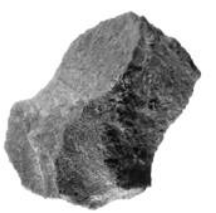

5

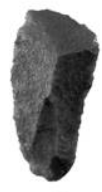

6

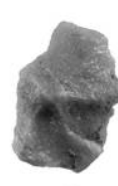

7

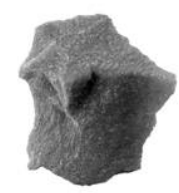

8

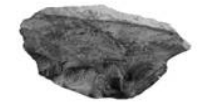

9

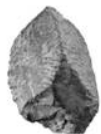

10

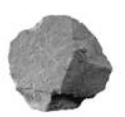

11

Figure 3. Quartzite and limestone Levallois products from level II. 1-3: Recurrent centripetal Levallois cores (quartzite); 4: Double scraper (quartzite); 5, 7, 8: Levallois flakes with use wear (quartzite); 6: Concave-convex double scraper on Levallois recurrent unidirectional flake (quartzite); 9-11: Levallois flakes (limestone).

To further the interpretation of these data we also need to consider two other aspects that relate raw material with knapping technique and the degree of use or transformation of the blanks obtained.

First, the percentage of Levallois blanks of all raw materials transformed by retouch is $25 \%$ or more in all three levels (Table 5). The frequency of all retouched and nonretouched blanks that were actually used as tools is likely to be higher, but confirmation depends on detailed studies of use wear that have yet to be carried out. Regarding quartzite, if we consider the material from all three levels, the degree of transformation $(34.56 \%)$ is higher than for flint $(27.56 \%)$. This might indicate that Levallois production on quartzite relates to a longer duration of blank 


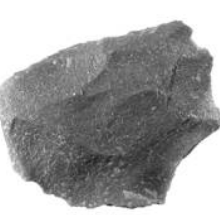

1

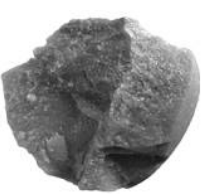

4
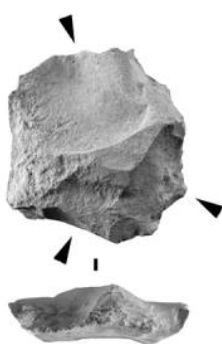

10

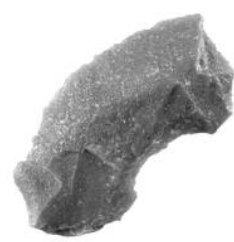

2
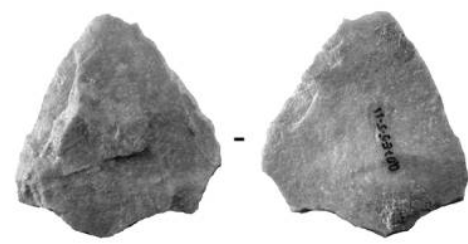

3

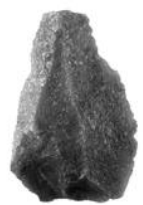

6

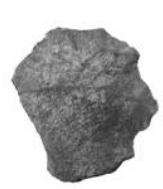

7

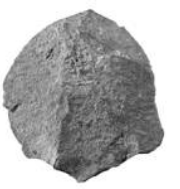

8

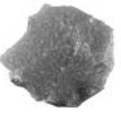

9

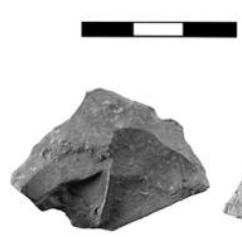

12

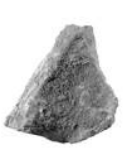

13

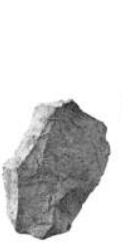

14

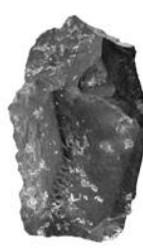

15

Figure 4. Quartzite and limestone Levallois products from level III. 1: Transversal convex scraper (quartzite); 2, 4, 5, 7-9: Levallois flakes (quartzite); 3: Convergent scraper (quartzite); 6: Levallois point (quartzite); 10: Levallois recurrent centripetal core reused as a scraper (limestone); 11, 12, 14: Levallois flakes (limestone); 13: Levallois point (limestone); 15: Atypical backed knife (limestone).

use-perhaps implying, at the stage of blank production, that special attention be given to the obtaining of shapes/volumes enabling subsequent resharpening—-and the more so since the unmodified blanks display regular edges that would not have required modification prior to use. Limestone pieces were clearly the least transformed (17.7\%), especially in level II, where only one formal tool was found; their production would seem to be linked to short durations of use entailing a lesser degree of edge resharpening.

Second is the issue of whether the choice of raw materials was influenced by toolsize considerations. Looking at the length and width of the Levallois blanks from the three levels (Figures 6-8) indicates that the blanks in the retouched sample are larger. This is usually the case for Middle Paleolithic lithic assemblages, especially when the impact of edge resharpening is not important, as is the case at Quebrada (Villaverde et al. 2012). 


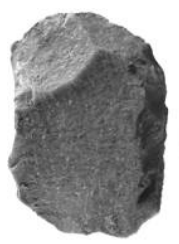

1

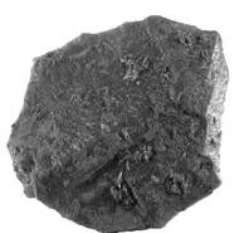

2

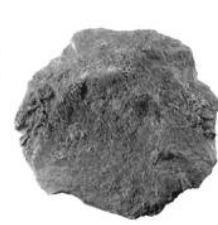

3

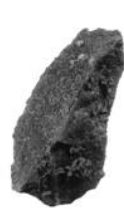

4

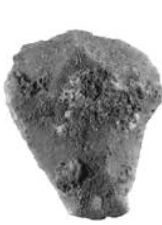

5

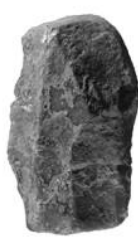

6

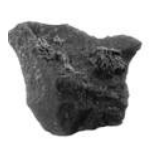

7

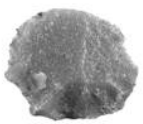

8

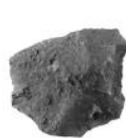

9

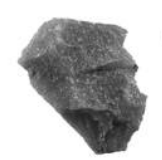

10

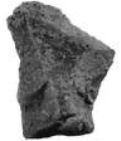

11

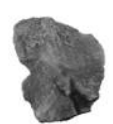

12

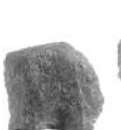

13

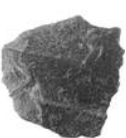

14

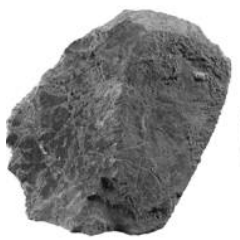

15

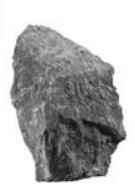

16

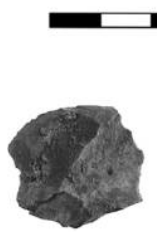

17

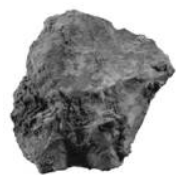

18

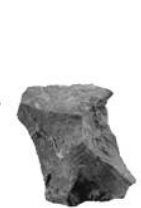

$19 \quad 20$

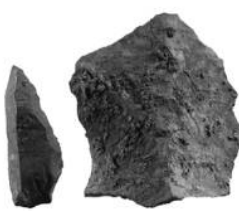

21

Figure 5. Levallois products from level IV. 1: Single straight scraper (quartzite); 2-5, 7-14: Levallois flakes (quartzite); 6: Single convex scraper (quartzite); 15: Transversal scraper (quartzite); 16-19, 21: Levallois flakes (limestone); 20: Arched-back point resembling Uluzzian (limestone).

In order to assess stratigraphic variation in blank size, we applied Student's $t$ test in the JMP Statistical Discovery from SAS, which uses an algorithm based on the comparison of the medians of the distributions. The option Each Pair, Student's $t$ computes individual pairwise comparisons using Student's $t$ tests. If you make many pairwise tests, there is no protection across the inferences. Therefore, the alpha (Type I error rate) across the hypothesis tests is higher than that for individual tests. Using Comparison Circles, each multiple comparison test begins with a plot, which is a visual representation of group mean comparisons. Visual Comparison of Group Means shows the comparison circles for the All Pairs, Tukey HSD method. Other comparison tests lengthen or shorten the radii of the circles. Compare each pair of group means visually by examining the intersection of the comparison circles. The outside angle of intersection tells you whether the group means are significantly different. Circles for means that are significantly different either do not intersect or intersect slightly, so the outside angle of intersection is less than $90^{\circ}$. If the circles intersect by an angle of more than $90^{\circ}$, or if they are nested, the means are not significantly different. And if the intersection angle is close to $90^{\circ}$, you can verify whether the means are significantly different.

The length, width, elongation (length $\div$ width), and area (length $\times$ width) of the Levallois products was found not to differ between the three levels studied. 
Table 5. Unretouched and retouched Levallois blanks by level and raw material

\begin{tabular}{lccr}
\hline & Unretouched & Retouched & Total \\
\hline Level II & $207(73.4 \%)$ & $75(26.6 \%)$ & 282 \\
Flint & $19(63.3 \%)$ & $11(36.6 \%)$ & 30 \\
Quartzite & $19(95 \%)$ & $1(5 \%)$ & 20 \\
Limestone & 245 & 87 & 332 \\
Subtotal & & & \\
\hline Level III & $270(75.6 \%)$ & $87(24.4 \%)$ & 357 \\
Flint & $31(62 \%)$ & $19(38 \%)$ & 50 \\
Quartzite & $28(77.8 \%)$ & $8(22.2 \%)$ & 36 \\
Limestone & $1(100 \%)$ & 0 & 1 \\
Quartz & 330 & 114 & 444 \\
Subtotal & $196(67.6 \%)$ & $94(32.4 \%)$ & 290 \\
Level IV & $39(69.6 \%)$ & $17(30.4 \%)$ & 56 \\
Flint & $18(78.3 \%)$ & $5(21.7 \%)$ & 23 \\
Quartzite & 253 & 116 & 369 \\
Limestone & & & \\
Subtotal & & &
\end{tabular}

This result was corroborated when alternative statistical tests used by other authors (Clarkson 2002; Eren et al. 2005; Kuhn 1990) were applied to the same dataset. However, our tests did show length and width differences between levels II and III, on one hand, and level IV, on the other. By raw material type, all levels combined, quartzite blanks were found to differ in length, and flint ones, in width. Within levels II and III, quartzite blanks are longer but have smaller areas than limestone ones; no such differences were observed within level IV.

In light of these results, we compared the elongation and area values for the different raw materials between levels II and III combined and level IV (Figure 9). Note that (a) flint blanks in levels II and III are longer and larger than those in level IV, (b) quartzite blanks are similar across the assemblages, and (c) limestone blanks are of identical length but of different area in level IV.

Overall, however, the variation observed in the dimensional parameters is so small, for both retouched and unretouched blanks, that it is difficult to conceive of raw material choice as having been motivated by the size of either the available nodules or the intended size of the blanks extracted from the cores prepared on such nodules. Therefore, it would seem that the selection of a given raw material was primarily dictated by suitability (of individual blocks of quartzite and of locally 


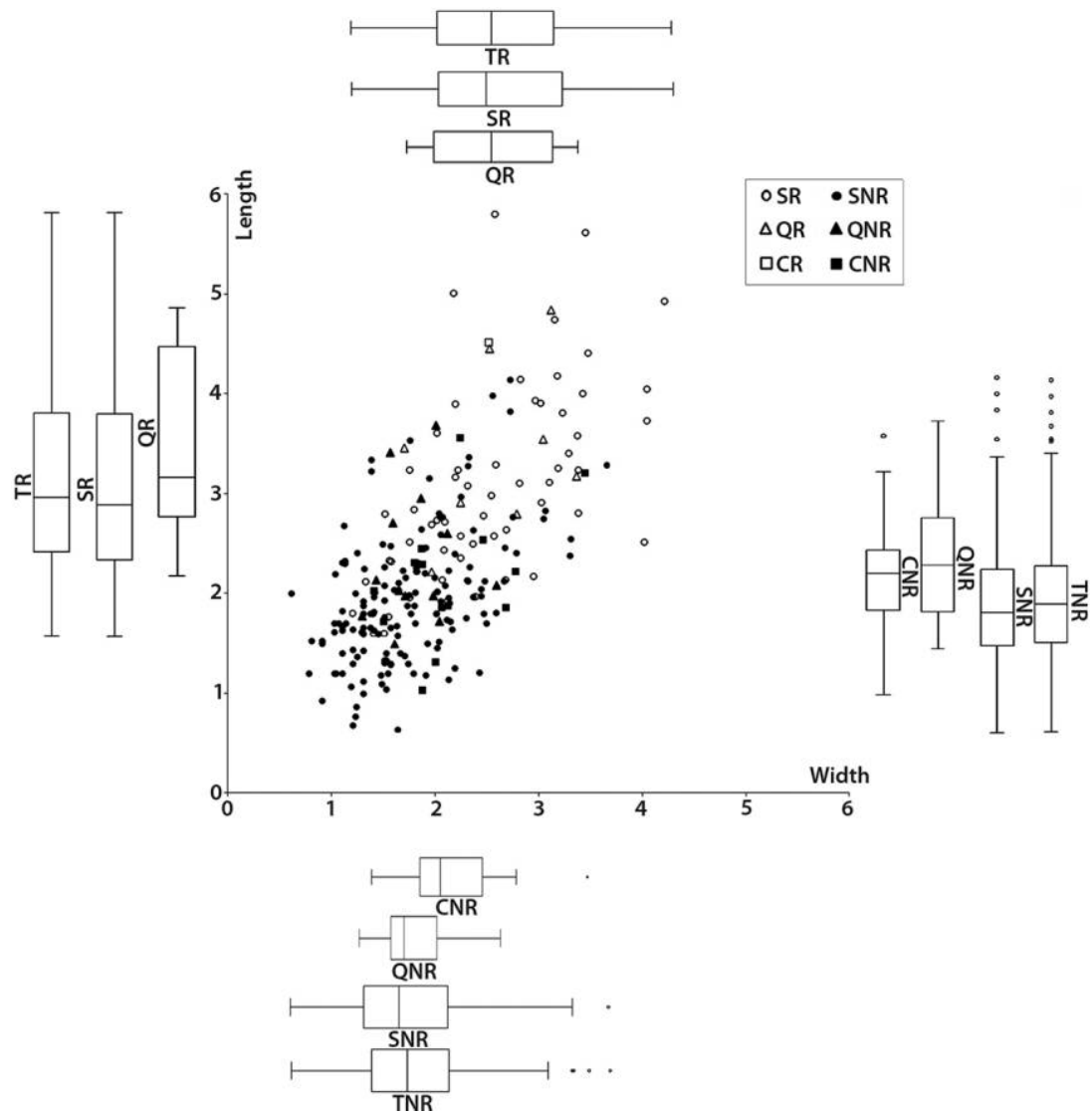

Figure 6. Level II scatter plot (length and width, in $\mathrm{cm}$ ) of Levallois retouched (including items with use wear) and unretouched flakes. The box plots represent the average (central bar), $50 \%$ of the cases (rectangle), $95 \%$ of the cases (whiskers), and outliers (dots).

TNR: Total unretouched; TR: Total retouched; SNR: Unretouched flint; SR: Retouched flint; QNR: Unretouched quartzite; QR: Retouched quartzite; CNR: Unretouched limestone.

available flints), on one hand, and by the degree of transformation and duration of use anticipated, in the case of limestone and quartzite blanks, on the other. That is to say, for reasons related to activities carried out on site, group mobility, and resource patchiness.

\section{DISCUSSION}

Levallois productions on raw materials other than flint have been documented for the Middle Paleolithic in different regions of the Iberian Peninsula (Figure 1). Lezetxiki VI (Álvarez and Arrizabalaga 2012), Arlanpe (Rios et al. 2011, 2015a), Axlor VII-VIII/M-N (González-Urquijo et al. 2005; Rios 2005), and Urrunaga 


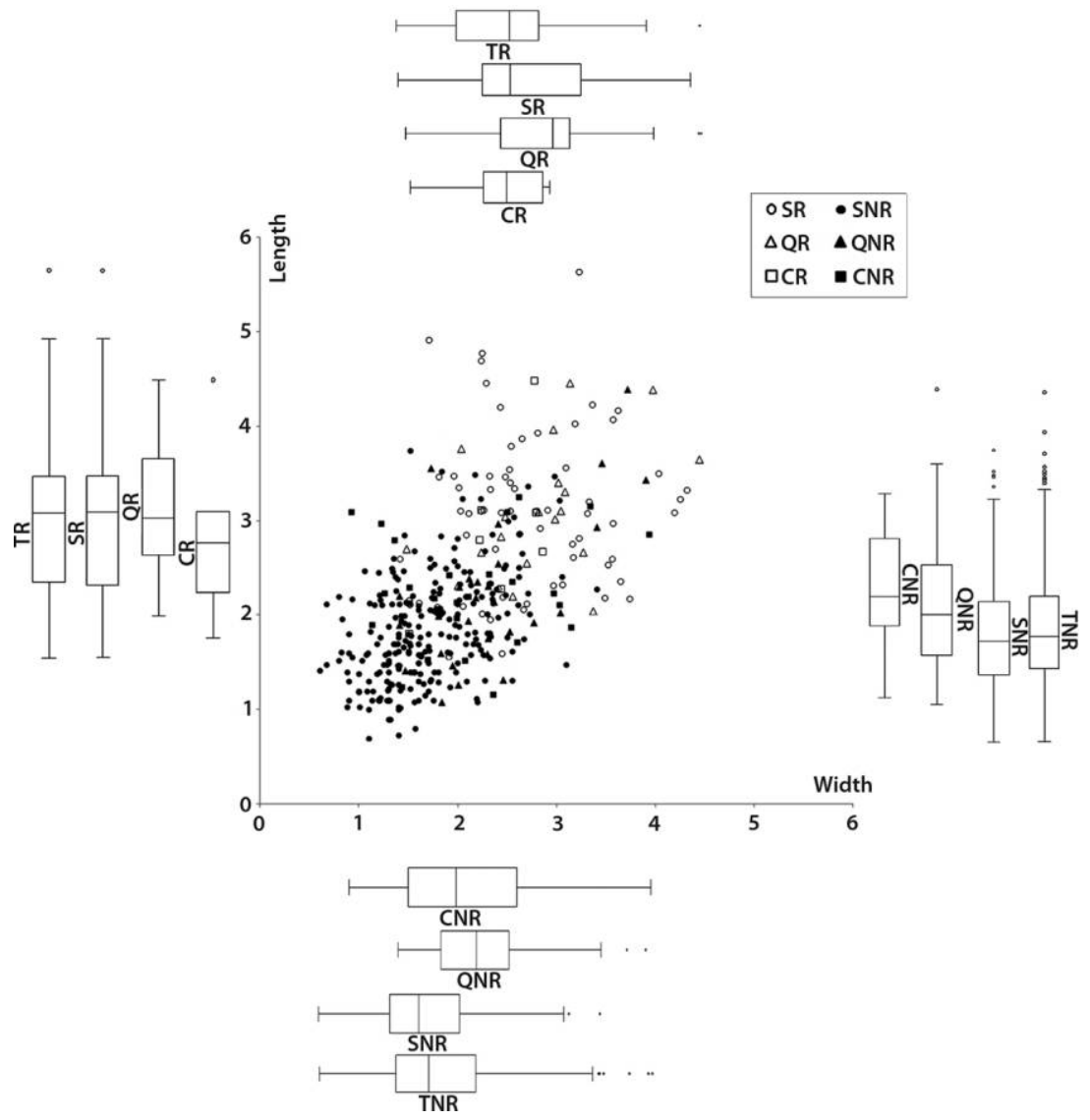

Figure 7. Level III scatter plot (length and width, in $\mathrm{cm}$ ) of Levallois retouched (including items with use wear) and unretouched flakes. The box plots represent the average (central bar), $50 \%$ of the cases (rectangle), $95 \%$ of the cases (whiskers), and outliers (dots).

TNR: Total unretouched; TR: Total retouched; SNR: Unretouched flint; SR: Retouched flint; QNR: Unretouched quartzite; QR: Retouched quartzite; CNR: Unretouched limestone; CR: Retouched limestone.

(Sáenz de Buruaga 1991) are examples of sites where the Levallois technique was used on mudstone. Levallois cores and blanks on diabase, vulcanite, and quartzite have been described in Amalda (Rios 2010), and level e of Peña Miel (Utrilla 1987) yielded Levallois cores on black lydite and quartzite.

Levallois preferential production on quartzite cores and with characteristic blanks has also been documented at a number of Spanish sites: namely, Amalda, level VII (Rios 2010); El Esquilleu, levels VI to XXIV, where the unidirectional recurrent modality, in particular, was identified in level IX, from level XVI to level XVIII, and in level XXIV, while the centripetal variety was identified in levels VI 


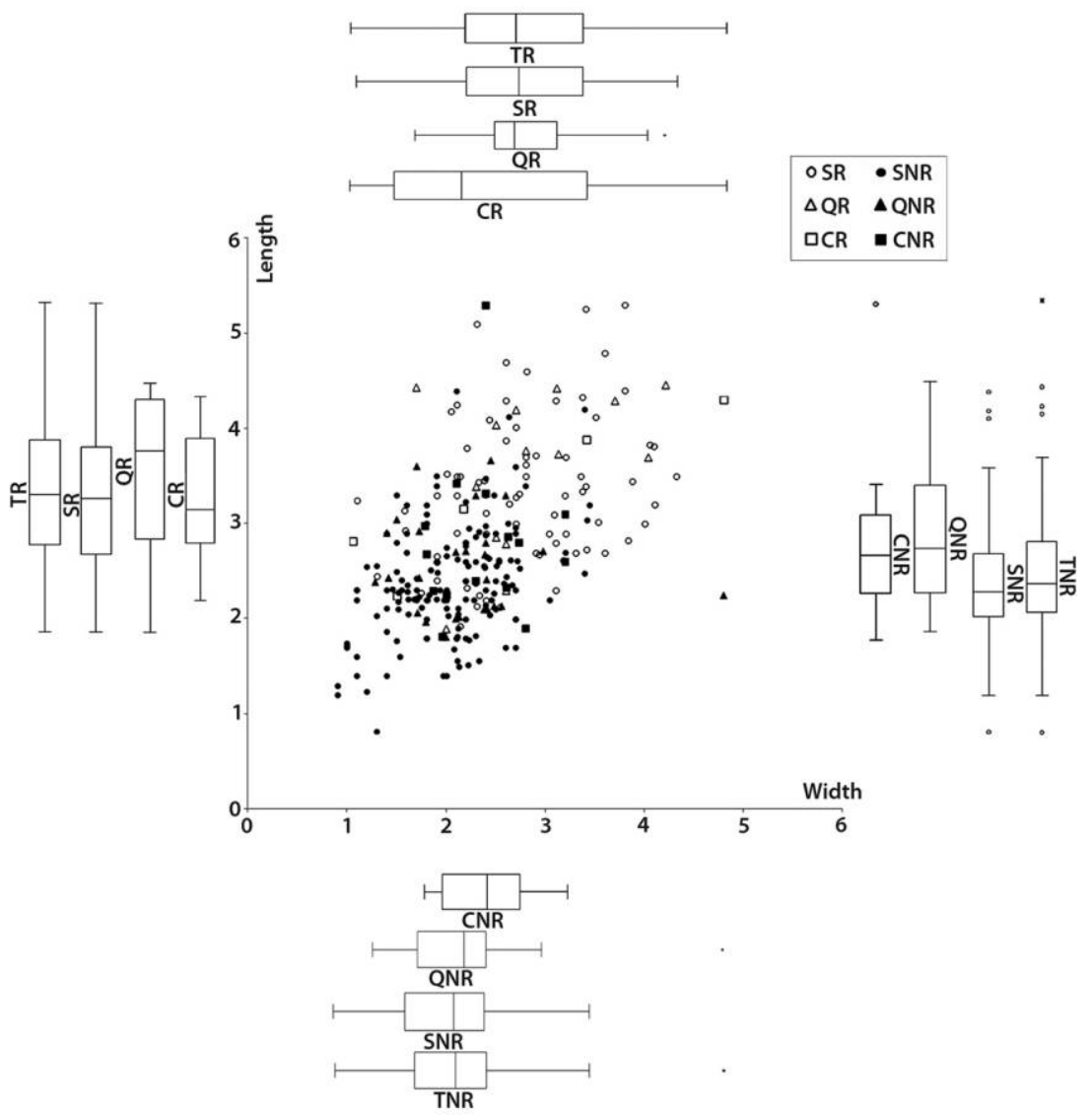

Figure 8. Level IV scatter plot (length and width, in $\mathrm{cm}$ ) of Levallois retouched (including items with use wear) and unretouched flakes. The box plots represent the average (central bar), 50\% of the cases (rectangle), 95\% of the cases (whiskers), and outliers (dots).

TNR: Total unretouched; TR: Total retouched; SNR: Unretouched flint; SR: Retouched flint; QNR: Unretouched quartzite; QR: Retouched quartzite; CNR: Unretouched limestone; CR: Retouched limestone.

and VII (Baena et al. 2005); El Castillo (level 20e), with a laminar Levallois production (Cabrera et al. 2001); La Viña (Santamaría 2012), where Levallois production on quartzite has been found in levels IB, IA+XV, XIV, XIV+IC, XIII basal and XIII inferior; and, finally, level e of Peña Miel (Utrilla 1987). Other sites with Levallois productions on quartzite but where the small number of finds precludes proper assessment are La Flecha (Castanedo 2001) and El Habario (Carrión and Baena 2005), with cores used for the extraction of points; level Cjr of Gatzarria (Laplace and Sáenz de Buruaga 2002-2003), with different types of Levallois blanks; and 


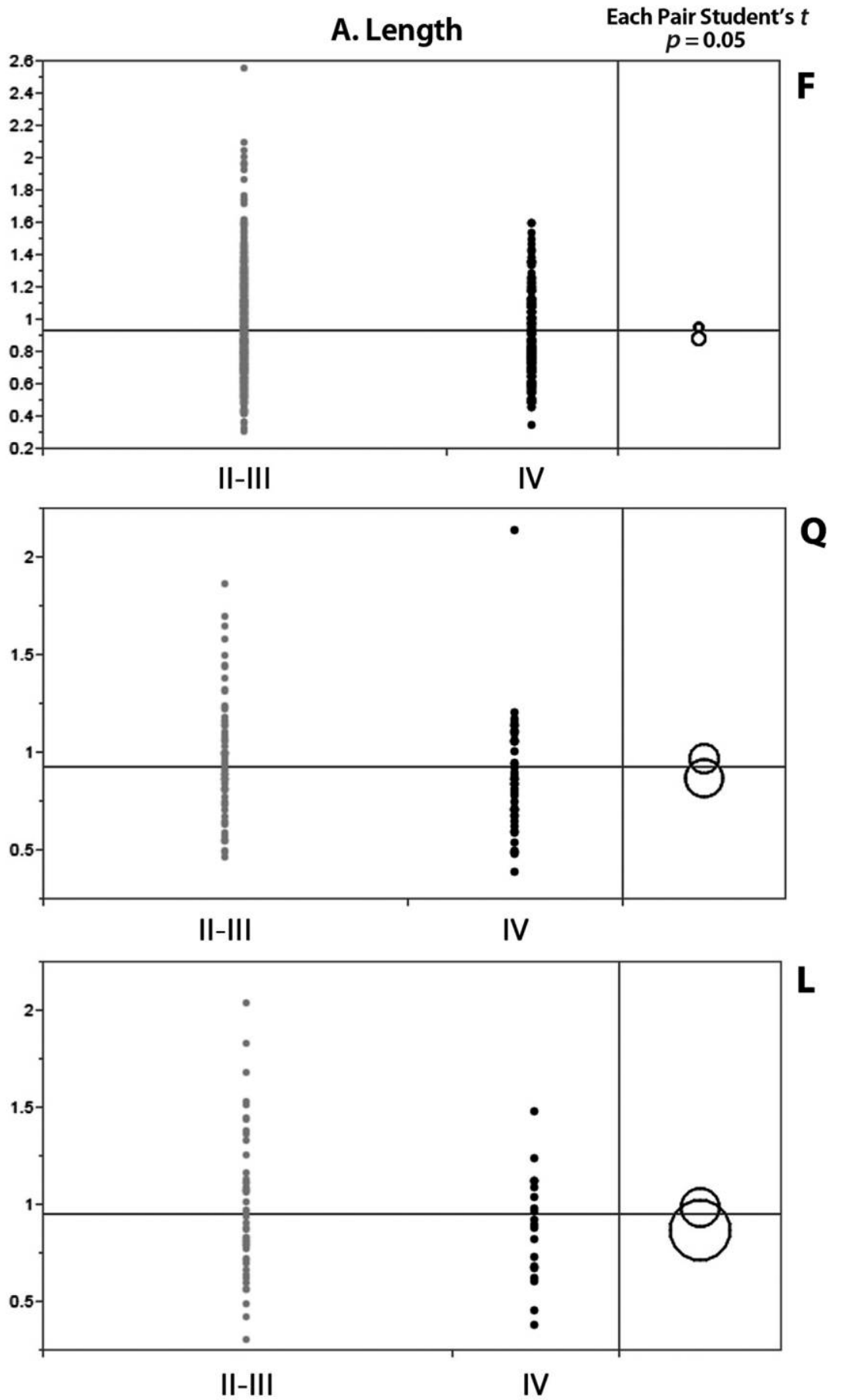

Figure 9. Student's $t$ results comparing levels II-III combined and level IV in (A) length and (B) area of Levallois blanks by raw material type. Top: flint, Middle: quartzite, Bottom: limestone. 

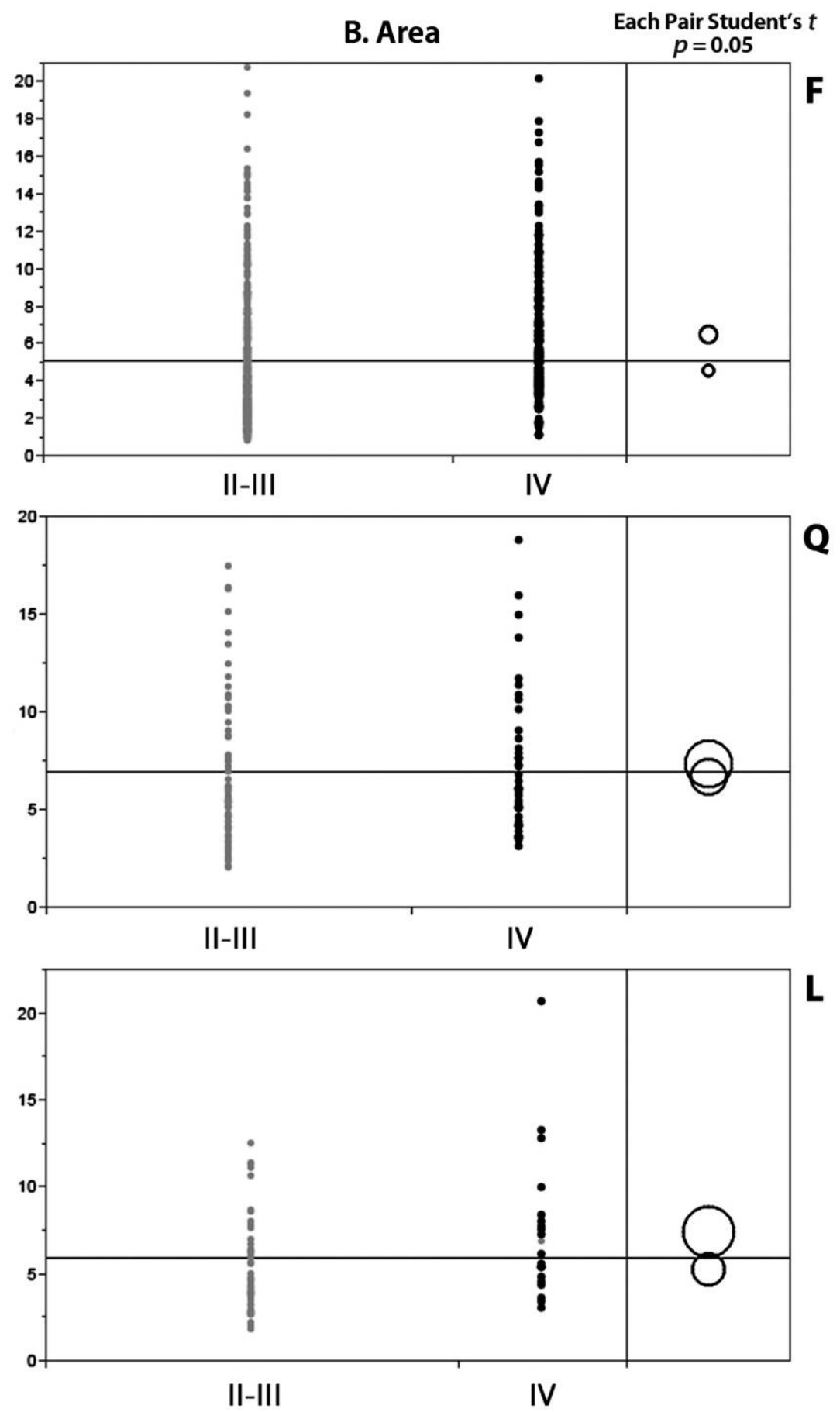

Figure 9 (Continued) 
level 4B of Cueva de la Güelga (Menéndez et al. 2005), with a preferential Levallois production and Levallois points (Table 6).

In Cantabria, quartzite was also widely used for laminar and microlaminar productions obtained from small cores, as in level 10 (defined as Châtelperronian) of Cueva Morín (Maíllo 2005b); level 18c (defined as "Transitional Aurignacian") of El Castillo, where a Levallois production on quartzite is also present (Cabrera et al. 2001); and the upper levels of La Viña (Santamaría 2012), just to mention a few cases. Although the homogeneity of the Morín and Castillo assemblages has been questioned, and the material found in level $18 \mathrm{c}$ of the latter suggests that a Mousterian component is present, the technological observation concerning the production of laminar and microlaminar blanks on quartzite remains valid regardless of debates concerning their exact chronology. This recourse to quartzite in western Cantabria is a consequence of the local unavailability of quality flint and is further illustrated later on by the well-known preference for quartzite in the making of concave-based points and other regional Solutrean weaponry.

In Portugal, where the use of quartzite is common throughout the Upper Paleolithic, particularly during the Solutrean (Pereira et al. 2012), Levallois productions on quartzite are documented at Oliveira, where flint, quartzite, and quartz are present in similar proportions but with variation in relative importance across the sequence (Marks et al. 2001; Zilhão et al. 2013). Non-flint Levallois productions are also documented at Vilas Ruivas (GEPP 1983) and Columbeira (Raposo and Cardoso 1998), where quartzite was used, and at Escoural (Silva et al. 1991), where they are on quartz.

In the peninsular northeast, the number of assemblages and finds is small, but the following can be mentioned: Roca dels Bous, levels N10 and N12 (Mora et al. 2008), with a production of very small quartzite blanks; Estret de Tragó, level UA3 (Mora et al. 1992); and finally, Cova Gran, level S1B (Martínez-Moreno et al. 2010), where a Levallois recurrent centripetal production has been documented. In the central Mediterranean area of the peninsula, leaving aside Abrigo de la Quebrada, isolated occurrences of quartzite pieces are documented at the sites of San Luís (Fernández Peris and Martínez Valle 1989), Árguinas-Majadal, and Hoya AlbaidaTitonares (Casabó y Rovira 2002).

Not much is known for the rest of the Iberian Peninsula. However, the application of the Levallois technique to quartzite has been mentioned for Tarazona III, levels 2 and 5 (Caro et al. 2013), and for the Porzuna surface collections (Vallespí et al. 1979, 1985). Additional examples are Canalizo del Rayo, Laguna del Polope, Cerro de la Cantera, Calderón del Moro, and la Rambla del Talave (López 19931994; López and Jordán 1995; Serna 1999).

Use of limestone in Middle Paleolithic Levallois production is poorly known. Besides Quebrada, the other known instances are Esquilleu, level XI (Baena et al. 2005), and Cueva Antón (Zilhão and Villaverde 2008). 
Examples of Levallois production on quartzite in Italy include Riparo Mochi, level I, where elongated pieces on sandy micro-quartzite have been documented (Yamada 1996). At La Rosa (Giunti 2000), recurrent centripetal and preferential pieces were found on the surface. In Arma delle Manie, level VII, the Levallois technique was applied not just to sandy micro-quartzite but also to quartz and limestone (Cauche 2002). In Madonna dell'Arma, levels Q, S, and IV (Cauche 2007), the raw material most used in Levallois productions is quartzite. This is also the case with Grotta delle Fate and Grotta del Colombo, where quartz was also used (Arobba et al. 2008; Mussi 2002). Finally, in Grotta del Principe, the main raw material is sandstone, but Levallois production is mostly on quartzite (Lumley 1971).

For France and Belgium, a number of recent papers mention the use of quartzite for Levallois production at sites such as Noisetier (Mourre and Thiébaut 2008), Tournal (Tavoso 1987), and Scladina level 5 (Di Modica and Bonjean 2009), whereas quartz is documented at La Borde (Jaubert et al. 1990). In North Africa, where quartzite predominates, Levallois industries of the Aterian have been recovered in levels III and VII of Contrebandiers (Bouzouggar 1997). This confirms that the absence of flint does not preclude the use of the Levallois method.

At most of the sites in the Iberian Peninsula where Levallois productions in raw materials other than flint have been found, the predominant raw material in a given level will also be that in which Levallois production is documented. We have many examples of this: El Esquilleu and La Viña, where the percentage of quartzite varies between $80 \%$ and $90 \%$ of the lithics; level $4 \mathrm{~B}$ of La Güelga, where it is $94 \%$; level 12 of Roca dels Bous, where it is $85 \%$ and flint, perhaps because of internal fissures that hinder the technique, is only used expediently (Mora et al. 2008); Gatzarria, where it represents 65\%; and El Habario level B, where it reaches 95\%. In some instances, quartzite is not the dominant raw material but was used for Levallois production. This is the case in Amalda, level VII, where quartzite is a mere 2\%; El Castillo, level 20 e, and Roca dels Bous, level N10, where quartzite is $32 \%$ of the material; and Estret del Tragó, level UA3, where quartzite reaches $40 \%$.

Only a few of the sites mentioned above are comparable to the particular situation documented here for Quebrada-namely, where flint is the raw material of choice but a significant percentage of Levallois production is on quartzite and other non-flint materials. Those sites are Amalda, level VII, and Roca del Bous, N10, where the non-flint raw material is quartzite; Lezetxiki, level VI, where it is mudstone; Riparo Mochi, level I, where it is sandy micro-quartzite; and San Francesco's surface level, where it is a siliceous limestone.

This review of the evidence confirms that no necessary link exists between the Levallois technique and a particular raw material, and that environmental determinism alone cannot explain the choice of knapping techniques, which raises interesting issues concerning the behavioral versatility of Neandertal groups. Given the importance of local availability in the Middle Paleolithic (Feblot-Augustins 


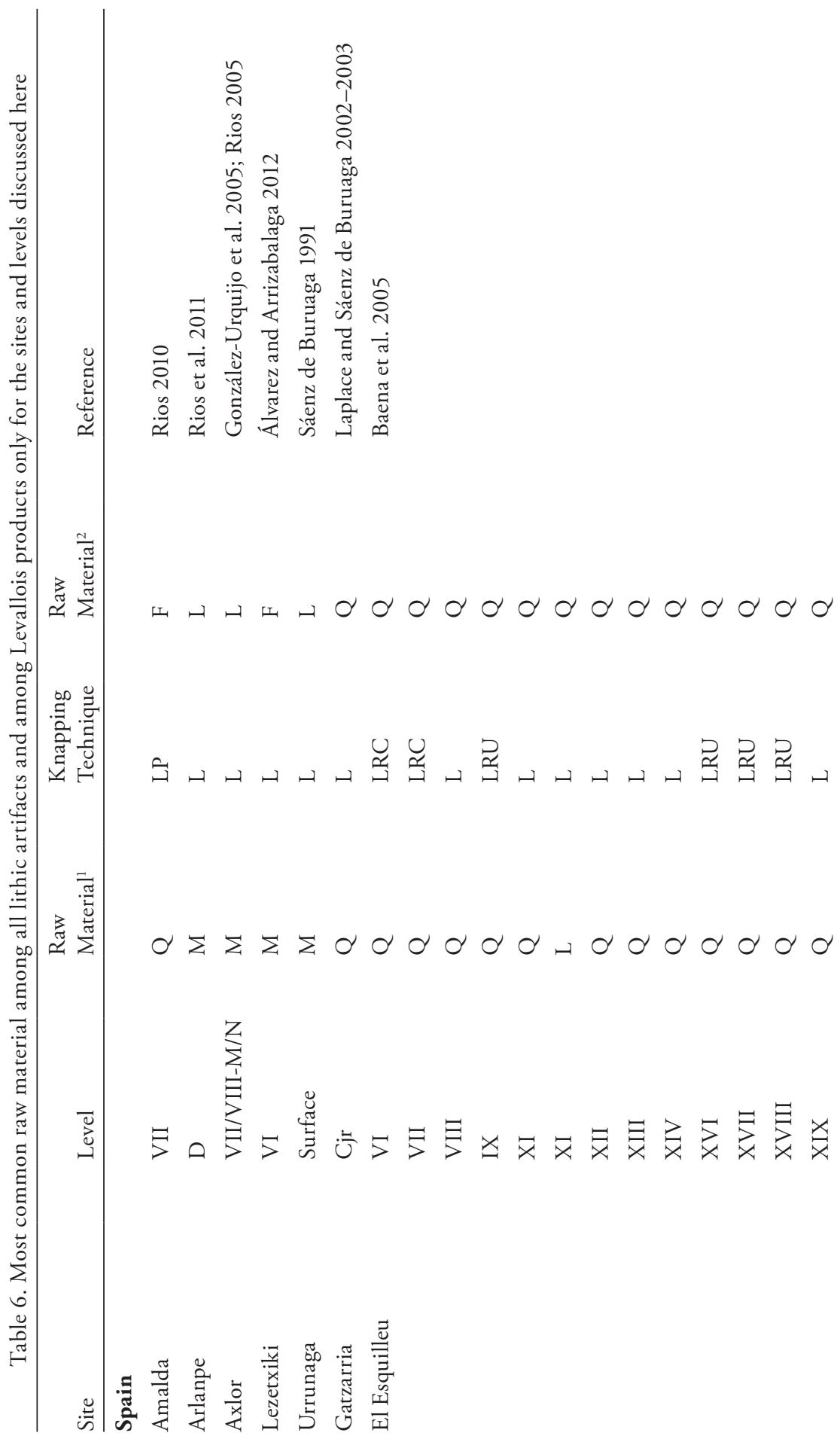




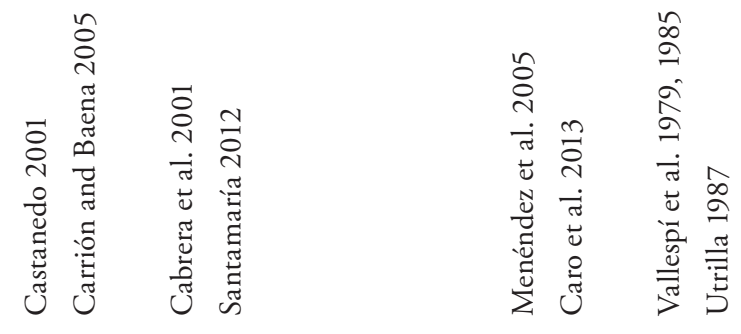

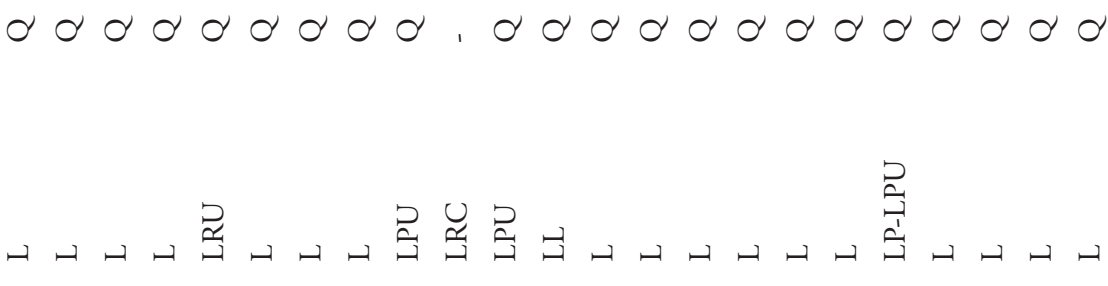

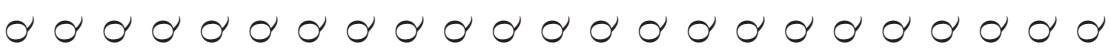

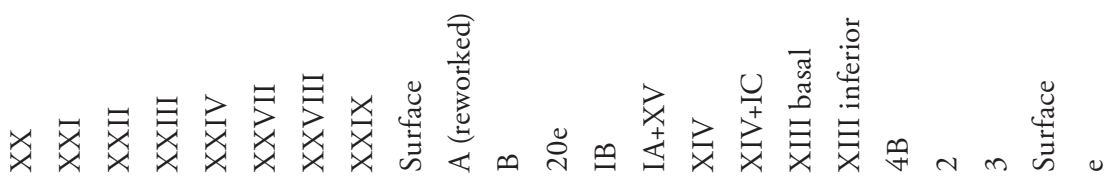
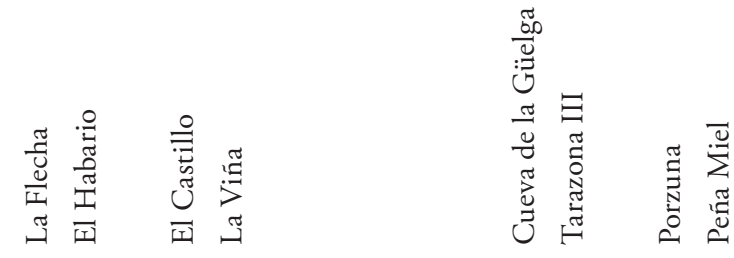


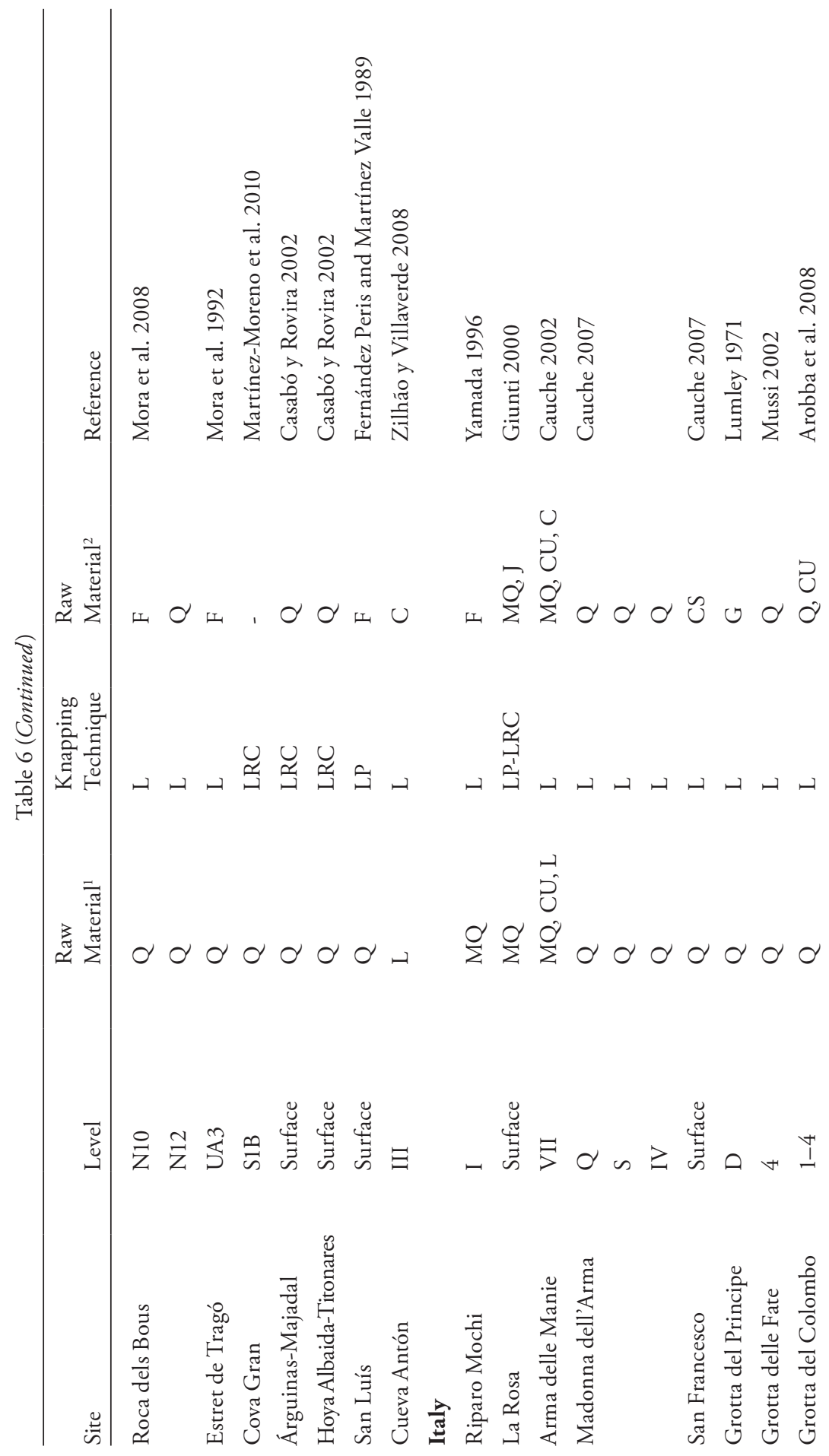




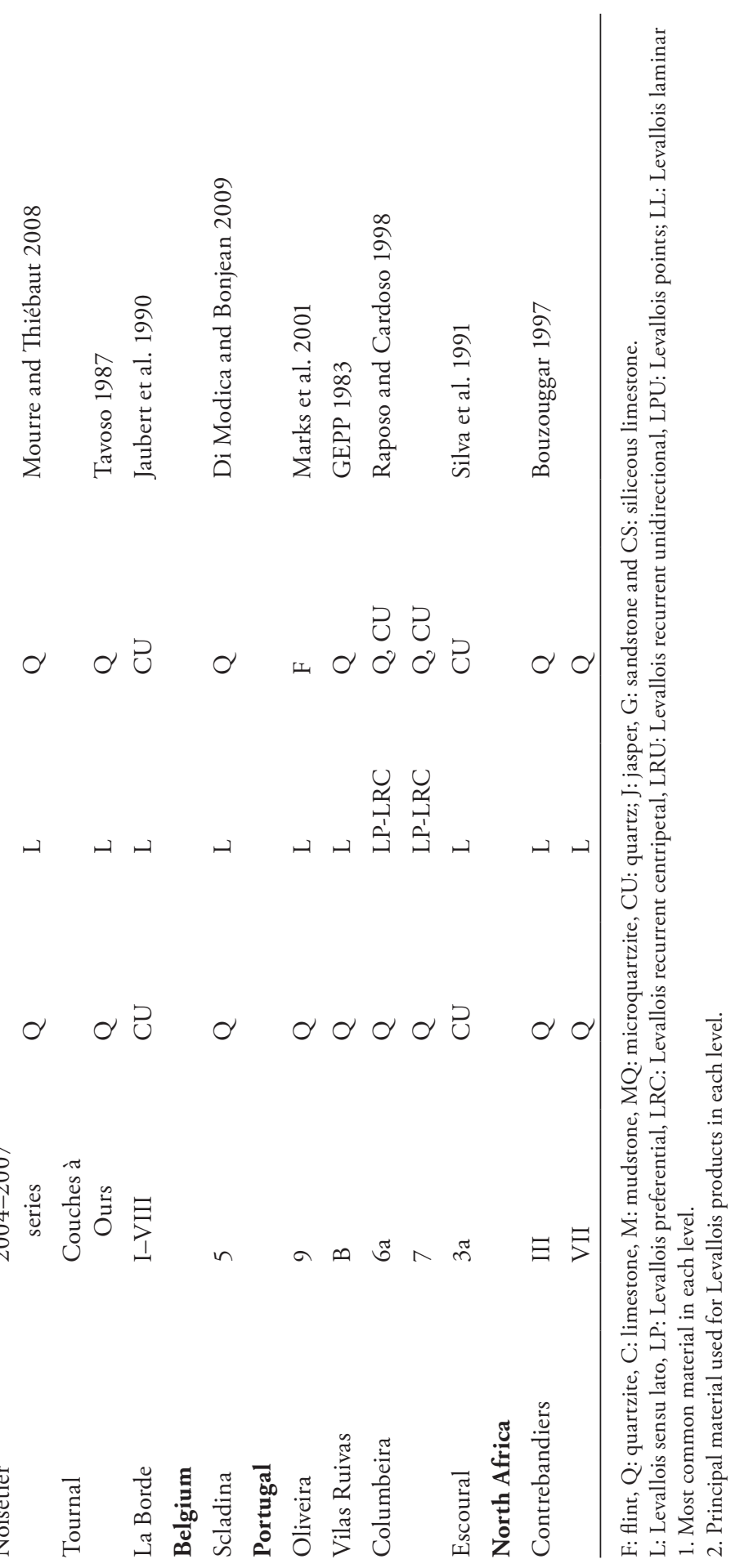


1999; Geneste 1988; Meignen 1988; Turq 1989), resorting to use of quartzite and limestone was unavoidable and predictable at such sites as La Viña, El Esquilleu, or El Castillo, where siliceous material sources are quite removed from immediate procurement areas (Baena et al. 2005; Rios 2010; Santamaría 2012). But in places with access to a variety of lithic resources, the choice of technique cannot be explained solely by availability factors. Particular raw materials with appropriate characteristics may have been preferred for the manufacturing of particular implements. And more durable raw materials may have been preferred when time budgeting issues were of significant concern. Such factors may have been at work in the cases of Amalda or Roca dels Bous.

Thus, both group mobility and variation in the quality of the raw materials available in the site's immediate procurement area could have influenced selection patterns. The use of non-flint raw materials in Levallois productions therefore needs to be assessed in connection with the length of occupation of a site and the activities carried out therein. For instance, in places of seasonal occupation and in the context of short-duration activities, such as hunting, raw material procurement could have been more expedient, and any suitable raw material available, flint or non-flint, could have been chosen for the production of Levallois blanks.

Support for this line of reasoning comes from the operative chain related to blank use rather than blank production. In the case of Quebrada, the diversity of raw materials on which the Levallois method was applied is accompanied by the limited extent to which knapping products are reduced by resharpening. This is an indication of short use biographies, in association with the butchery and consumption of hunted animals (Geneste and Plisson 1996; González-Urquijo and Ibáñez 1994; Plisson 1985, 1986).

In cases such as these, long journeys to obtain a particular raw material would not have been economical because the group only stayed at the site for a short period and the lithic tools produced there were used for a limited amount of time. This is even more likely when, as at Quebrada, cobbles of fine-grained quartzite of homogeneous structure and adequate size, as well as of suitable limestone and reasonable quality flint, exist in the immediate surroundings.

Conceivably, the raw material diversity seen in the Quebrada Levallois products and the use of the discoid technique could relate to issues of visibility and accessibility. Arguments of this kind, linking the choice of technique with the visibility of raw material sources, have been proposed to explain the products of the Quina technique in some Middle Paleolithic sites in southwest France (Turq 1992) - the argument being that the Quina method provides for long edge-resharpening biographies and, therefore, is very economical when raw materials are difficult to obtain.

However, the situation at Quebrada is different. Given the palimpsest nature of the archaeological levels, the coexistence of Levallois and discoid products does not imply that they were used coevally since they could instead represent technical solutions used in the context of different, albeit close in time, episodes of occupation; 
even in this latter case, however, the temporal intervals involved would have been insufficient for changes in raw material visibility to have occurred. In addition, even though the increase in quartzite and limestone is accompanied in level IV by an increase in the percentage of discoid blanks, these raw materials are also documented among that level's Levallois products.

The choice of a given technique could have been influenced by cultural tradition, but assessing the impact of this factor is, in our opinion, a difficult task. Therefore, other factors have to be considered first. The fact that, at Quebrada, discoid blanks are more often transformed by retouch than Levallois ones may be a particular indication of the importance of functional factors, since the more expedient nature of the discoid method is consistent with occupations of a more temporary or seasonal nature-ones in which resharpening of blanks available on-site would have been more economical than producing ex novo from suitable nodules whose acquisition, even at a short distance, would nonetheless have demanded an investment in time.

In support of this hypothesis, we note that the sedimentological and anthracological evidence, the latter indicative of a vegetation dominated by Pinus nigra (Badal et al. 2012), suggests that the levels analyzed here formed under harsh climatic conditions; considering these conditions and the elevation of the site $(790 \mathrm{~m}$ above sea level), it is therefore very likely that it was regularly covered by snow and, hence, unoccupied. In addition, there are some indications that the choice of knapping method may have some relation to the use of space and the processing of the hunt (Eixea et al. 2011-2012). In level IV, for instance, a structured use of the habitation space is indicated by a concentration of discoid cores found at its base, by the fact that the remains of cervids tend to cluster separately from those of equids and ibex, and by a concentration of tortoise remains in the central part of the excavated area. Overall, we therefore feel that the data from Quebrada can be interpreted in light of Andresfsky's (1994) observations concerning the important role played by raw material procurement and selection in relation to territorial mobility and technological expediency (Parry and Kelly 1987; Wallace and Shea 2006).

The variety of raw materials used in Iberian Levallois production is a clear indication of the flexibility that characterized the behavior of Neandertal groups. The pattern documented at Quebrada, for instance, contrasts with what we know about the Middle Paleolithic in the central Mediterranean region, where flint is almost exclusively used, representing more than $85-90 \%$ of the industry, as documented at nearby Tossal de la Font, El Pinar, Cova Beneito, Cueva del Cochino, El Salt, or Abric del Pastor. Slightly lower values are found at San Luis, where quartzite reaches $20 \%$, but this is a small surface collection whose homogeneity is open to question.

These data suggest that the choice of technique is not a mere reflection of the availability of raw materials but can be the result of different factors, such as length of occupation, number of individuals occupying the site, the tasks for which the tools were prepared, and the function of the settlement. The evidence from Quebrada supports the notion that Neandertal groups were flexible in their choice of 
knapping methods, which would have resulted from the application to concrete situations of their general knowledge of raw material properties and the possibilities and constraints of the different stone tool production techniques available to them.

This pattern of behavior is also apparent in the use of multiple technological systems (Bourguignon et al. 2004; Rios et al. 2015b), the change of method in the course of reduction sequences as a function of the kinds of blanks sought and the tasks they were intended to perform (Jaubert and Farizy 1995; Lenoir and Turq 1995; Mourre 2003; Slimak 1998-1999; Terradas 2003), or the production of small blanks even when available raw material blocks pose no limitations on the size of debitage produced (Bordes 1981; Dibble and McPherron 2006; Goren Inbar 1988; Koumouzelis et al. 2001; Kuhn and Elston 2002; Moles and Boutié 2009; Moncel 2003; Mora et al. 2004; Rios 2010; Turq et al. 2008; Villaverde et al. 2012). Rather than being the manifestation of a non-reflective, mechanic repetition of traditional practice, this behavior is typical of cultural know-how and experience that is transmitted generationally and adaptively modified when needed.

In this context, the particular insight that can be gained from Quebrada is that in situations of high mobility across territories characterized by discontinuity in raw-material sources, more attention must be given to the duration of the edges, which in turn means a choice of raw materials that guarantee longer resharpening histories. Conversely, in techno-economic systems characterized by a low incidence of resharpening, where production is followed by use and immediate discard, duration may not be an important factor, especially when mobility is not as high and suitable raw materials are locally abundant. Reasons such as these may help to explain why flint, quartz, limestone, and quartzite are used indiscriminately when their sources are situated at comparable distances from a given site.

\section{NOTE}

Research carried out for this paper has benefited from the following: "El final del Paleolítico medio y el Paleolítico superior en la región central del Mediterráneo ibérico" (FFI 2008-01200/FISO), "La conducta de los neandertales: una aproximación a partir del registro arqueológico del Abrigo de la Quebrada (Chelva, Valencia)" (HAR 2008-04273-E/HIST), "Paleolítico medio final y Paleolítico superior inicial en la región central mediterránea (Valencia y Murcia)" and "Mas allá de la Historia: los inicios del poblamiento paleolítico valenciano” (PROMETEOII/2013/016).

\section{REFERENCES CITED}

Álvarez, D., and A. Arrizabalaga. 2012. La secuencia inferior de la cueva de Lezetxiki (Arrasate, País Vasco): Una reflexión necesaria. Zephyrus LXIX:15-39.

Andrefsky, W. 1994. Raw material availability and the organization of technology. American Antiquity 59(1):21-34. 
Arobba, D., G. Boschian, R. Caramiello, A. Giampietri, F. Negrino, and C. Tozzi. 2008. "La Grotta del Colombo: Indagini geoarcheologiche, palinologiche e sull'industria litica," in Toirano e la Grotta della Bàsura, Atti del Convegno, Bordighera. Edited by D. Arobba, R. Maggi, and G. Vicino, pp. 69-88.

Arrizabalaga, A., and J. Rios. 2012. The first human occupation of the Basque crossroads. Lournal of World Prehistory 25:157-81.

Badal, E., V. Villaverde, and J. Zilhão. 2012. Middle Paleolithic wood charcoal from three sites in south and west Iberia: Biogeographic implications. Saguntum (Extra-13):13-24.

Baena, J., E. Carrión, B. Ruíz, B. Ellwood, C. Sesé, J. Yravedra, J. Jordá, P. Uzquiano, R. Velázquez, I. Manzano, A. Sánchez-Marco and F. Hernández. 2005. "Paleoecología y comportamiento humano durante el Pleistoceno superior en la comarca de Liébana: La secuencia de la Cueva de El Esquilleu (Occidente de Cantabria, España)," in Neandertales cantábricos: Estado de la cuestión. Edited by R. Montes and J. A. Lascheras, pp. 461-87. Monografías del Museo Nacional y Centro de Investigación de Altamira 20. Madrid: Ministerio de Cultura.

Boëda, E. 1991. Approche de la variabilité des systèmes de production lithique des industries du Paléolithique inférieur et Moyen: Chronique d’une variabilité attendue. Techniques et Culture 17-18:37-79.

-1993. Le débitage discoïde et le débitage levallois récurrent centripète. Bulletin de la Société Préhistorique Française 90:392-404.

— 1994. Le concept Levallois: Variabilité des méthodes. CRA Monograph 9. Paris: CNRS.

Boëda, E., J-M. Geneste, and L. Meignen. 1990. Identification de chaînes opératoires lithiques du Paléolithique ancien et moyen. Paléo 2:43-80.

Bourguignon, L., J.-P. Faivre, and A. Turq. 2004. Ramification des chaînes opératoires: Une spécificité du Moustérien? Paléo 16:37-48.

Bouzouggar, A. 1997. Matières premières, processus de fabrication et de gestion des supports d'outils dans la séquence atérienne de la grotte des Contrebandiers à Temara. PhD dissertation, Université de Bordeaux.

Bordes, F. 1981. Vingt-cinq ans aprés: Le complexe moustérien revisité. Bulletin de la Société Préhistorique Française 78:77-87.

Cabrera, V., J. M. Maíllo, M. Lloret, and F. Bernaldo de Quirós. 2001. La transition vers le Paléolithique supérieur dans la grotte du Castillo (Cantabrie, Espagne): La couche 18. L'Anthropologie 105:505-32.

Caro, J. A., F. Díaz, R. Cámara, J. M. López Recio, and C. Borja. 2013. Geoarchaeological alluvial terrace system in Tarazona: Chronostratigraphical transition of Mode 2 to Mode 3 during the Middle-Upper Pleistocene in the Guadalquivir River valley (Seville, Spain). Quaternary International 243:143-60.

Carrión, E., and J. Baena. 2005. "El Habario: Una ocupación musteriense al aire libre en los Picos de Europa," in Neandertales cantábricos: Estado de la cuestión. Edited by R. Montes and J. A. Lascheras, pp. 443-60. Monografías del Museo Nacional y Centro de Investigación de Altamira 20. Madrid: Ministerio de Cultura.

Casabó, J., and M. L. Rovira. 2002. El Paleolítico medio en el valle del Palancia. Saguntum 34:9-28. 
Castanedo, I. 2001. Adquisición y aprovechamiento de los recursos líticos en la Cueva de La Flecha (Cantabria). Munibe 53:3-18.

Cauche, D. 2002. Les cultures moustériennes en Ligurie italienne: Étude des industries lithiques des grottes de la Madonna dell'Arma, d'Arma delle Manie et de Santa Lucia Superiore. PhD dissertation, Université de la Méditerranée Aix-Marseille II.

- 2007. Les cultures moustériennes en Ligurie italienne: Analyse du matériel lithique de trois sites en grotte. L'Anthropolooie 111:254-89.

Clarkson, C. 2002. An index of invasiveness for the measurement of unifacial and bifacial retouch: A theoretical, experimental and archaeological verification. Lournal of Archaeolooical Science 29:65-75.

Dibble, H., and S. McPherron. 2006. The missing Mousterian. Current Anthropology 47: 777-803.

Di Modica, K., and F. Bonjean. 2009. "The exploitation of quartzite in layer 5 (Mousterian) of Scladina Cave (Wallonia, Belgium): Flexibility and dynamics of concepts of debitage in the Middle Palaeolithic," in Technological analysis on quartzite exploitation/Études technologiques sur l'exploitation du quartzite. Edited by S. Grimaldi and S. Cura, pp. 33-41. BAR International Series 1998. Oxford: Archaeopress.

Eixea, A. 2012. Aprovechamiento de las calizas en el Paleolítico medio del Abrigo de la Quebrada (Chelva, Valencia). Archivo de Prehistoria Levantina XXIX:53-64.

Eixea, A., V. Villaverde, C. Roldán, and J. Zilhão. 2014. Middle Palaeolithic flint procurement in Central Mediterranean Iberia: Implications for human mobility. Iournal of Lithic Studies 1:103-15.

Eixea, A., V. Villaverde, and J. Zilhão. 2011. Aproximación al aprovisionamiento de materias primas líticas en el yacimiento del Paleolítico medio del Abrigo de la Quebrada (Chelva, Valencia). Trabaios de Prehistoria 68:65-78.

Eixea, A., V. Villaverde, J. Zilhão, A. Sanchis, J. Morales, C. Real, and M. Bergadà. 20112012. El nivel IV del Abrigo de la Quebrada (Chelva, Valencia): Análisis microespacial y valoración del uso del espacio en los yacimientos del Paleolítico medio valenciano. Mainake XXXIII:127-58.

Eren, I., M. Domínguez-Rodrigo, S. Kuhn, D. S. Adler, I. Le, and O. Bar-Yosef. 2005. Defining and measuring reduction in unifacial stone tools. Lournal of Archaeolooical Science 32:1190-1201.

Feblot-Augustins, J. 1999. "Raw material transport patterns and settlement systems in the European Lower and Middle Palaeolithic: Continuity, change and variability," in The Middle Palaeolithic Occupation of Europe. Edited by W. Roebroeks and C. Gamble, pp. 193-214. University of Leiden.

Fernández Peris, J., and R. Martínez Valle. 1989. El yacimiento del Paleolítico medio de San Luis (Buñol, Valencia). Saguntum 22:11-34.

Geneste, J.M. 1988. "Systemes d'approvisionnement en matieres premieres au paléolithique moyen et au paléolithique supérieur en Aquitaine," in L'Homme de Neandertal. Edited by M. Otte, pp. 61-70. Universite de Liège.

1997. Lutilisation du quartz au Paléolithique moyen dans le nord-est du Bassin Aquitain. Préhistoire Anthropologie Méditerranéennes 6:259-79.

Geneste, J. M., and H. Plisson. 1996. Production et utilisation de l'outillage litique dans le Moustérien du Sud-ouest de la France: Les Tares à Sourzac, vallée de l'Isle, Dordogne. Quaternaria 6:149-66. 
GEPP (Grupo para o Estudo do Paleolítico Português). 1983. A estação paleolítica de Vilas Ruivas (Ródão), campanha de 1979. O Arqueólogo Português IV(1):15-38.

Giunti, P. 2000. Una industria litica del Pleistocene medio recente dalla località La Rosa in Val d'Era, Pisa (Toscana), I: Tecnologia dell'industria litica. Rassegna di Archeologia 17:9-33.

González-Urquijo, J., and J. J. Ibáńez. 1994. Metodología de análisis funcional de instrumentos tallados en sílex. Cuadernos de Arqueología 14. Bilbao: Universidad de Deusto.

González-Urquijo, J., J. J. Ibáńez, J. Rios, L. Bourguignon, P. Castaños, and A. Tarriño. 2005. "Excavaciones recientes en Axlor (2000-2003): El final del Paleolítico Medio," in Neandertales Cantábricos. Estado de la cuestión, Edited by R. Montes and J. A. Lascheras, pp. 527-39. Monografías del Museo Nacional y Centro de Investigación de Altamira 20. Madrid: Ministerio de Cultura.

Goren Inbar, N. 1988. Too small to be true? Reevaluation of cores on flakes in Levantine Mousterian assemblages. Lithic Technoloogy 17(1):37-44.

Jaubert, J., and C. Farizy. 1995. "Levallois débitage: Exclusivity, absence or coexistence with other operative schemes in the Garonne Basin, southwestern France," in The definition and interpretation of Levallois technology. Edited by H. Dibble and O. Bar-Yosef, pp. 22748. Madison: Prehistory Press.

Jaubert, J., M. Lorblanchet, H. Laville, and R. Slott-Moller. 1990. Les chasseurs d'aurochs de La Borde: Un site du Paléolithique moyen. Maison des Sciences de l'Homme 27. Paris.

Koumouzelis, M., J. Kozlowski, C. Escutenaire, V. Sitlivy, K. Sobczyk, H. Valladas, N. Tinesrat-Laborde, P. Wojtal, and B. Ginter. 2001. La fin du Paléolithique moyen et le début du Paléolithique supérieur en Grèce: La séquence de la Grotte 1 de Klissoura. L'Anthropologie 105:469-504.

Kuhn, S. 1990. A geometric index of reduction for unifacial stone tools. Journal of Archaeological Science 17:583-93.

Kuhn, S., and R. Elston. 2002. "Thinking small globally," in Thinking small: Global perspectives on microlithization. Edited by R. Elston and S. Kuhn, pp. 1-7. Arlington, VA: American Anthropological Association.

Laplace, G., and A. Sáenz de Buruaga, A. 2002-2003. Typologie analytique et structurale des complexes du mustérien de la Grotte Gatzarria (Ossas-Suhare, Pays Basque) et leurs relations avec ceux de l'Abri Olha 2 (Cambo, Pays Basque). Pyrenae 33-34:81-163.

Lenoir, M., and A. Turq. 1995. "Recurrent centripetal debitage (Levallois and discoidal): Continuity or discontinuity?" in The definition and interpretation of Levallois technology. Edited by H. Dibble and O. Bar-Yosef, pp. 249-56. Madison: Prehistory Press.

Locht, J.-L. 2003. "L'industrie lithique du gisement de Beauvais (Oise, France): Objectifs et variabilité du débitage discoïde," in Discoid lithic technology. Advances and implications. Edited by M. Peresani, pp. 193-208. BAR International Series 1120. Oxford: Archaeopress.

López, M. 1993-1994. Yacimientos musterienses al aire libre de la región de Murcia y sur de Albacete: Pautas de asentamiento, incidencia de la materia prima y variabilidad de la industria lítica. Anales de Prehistoria y Arquelogía 9-10:5-22.

López, M., and J. F. Jordán. 1995. El yacimiento musteriense de la laguna de "El Polope" (Tobarra, Albacete). Al-Basit 37:5-35.

Lumley, H. de. 1971. Le Paléolithique inférieur et moyen du midi Mediterranéen dans son cadre géologique. Paris: Editions du Centre National de la Recherche Scientifique. 
Maíllo, J. M. 2005a. "Esquemas operativos líticos del Musteriense final de Cueva Morín (Villanueva de Villaescusa, Cantabria)," in Neandertales cantábricos: Estado de la cuestión. Edited by R. Montes and J. A. Lascheras. pp. 301-13. Monografías del Museo Nacional y Centro de Investigación de Altamira 20. Madrid: Ministerio de Cultura.

-2005b. La producción laminar en el chatelperroniense de Cueva Morín: Modalidades, intenciones y objetivos. Trabajos de Prehistoria 62:47-64.

Marks, A., K. Monigal, and J. Zilháo. 2001. "The lithic assemblages of the Late Mousterian at Gruta da Oliveira, Almonda, Portugal," in Les premiers hommes modernes de la Péninsule Ibérique. Edited by J. Zilhão, T. Aubry, and A. F. Carvalho, pp. 145-54. Actes du Colloque de la Commission VIII de I’UISPP, Vila Nova de Foz Coa, Octobre 1998. Trabalhos de Arqueologia 17. Lisboa: Instituto Português de Arqueologia.

Martínez-Moreno, J., R. Mora, and I. de la Torre. 2010. The Middle-to-Upper Palaeolithic transition in Cova Gran (Catalunya, Spain) and the extinction of Neanderthals in the Iberian Peninsula. Iournal of Human Evolution 58:211-26.

Meignen, L. 1988. "Une exemple de comportement technologique différentiel selon les matières premières: Marillac, couches 9 et 10," in L'Homme de Neandertal. Edited by M. Otte, pp. 71-79. Universite de Liège.

Menéndez, M., E. García, and J. M. Quesada. 2005. "La transición Paleolítico medio-Paleolítico superior en la Cueva de la Güelga (Cangas de Onís, Asturias): Un avance a su registro," in Neandertales cantábricos: Estado de la cuestión. Edited by R. Montes and J. A. Lascheras, pp. 589-617. Monografías del Museo Nacional y Centro de Investigación de Altamira 20. Madrid: Ministerio de Cultura.

Moles, V., and P. Boutié. 2009. Contribution à la reconnaissance d'une microproduction au Paléolithique moyen: les industries de la grotte des Ramandils (Port-La Nouvelle, Aude, France). L'Anthropologie 113:356-80.

Moncel, M.-H. 2003. "L'exploitation des petits galets dans les assemblages microlitiques du Paléolithique moyen d'Europe centrale: Külna et Predmosti en République tchèque, Tata en Hongrie," in Discoid lithic technology: Advances and implications. Edited by M. Peresani, pp. 225-39. BAR International Series 1120. Oxford: Archaeopress.

Moncel M.-H., J. P. Brugal, A. Prucca, and G. Lhomme. 2008. Mixed occupation during the Middle Palaeolithic: Case study of a small pit-cave-site of Les Pêcheurs (Ardèche, south-eastern France). Lournal of Anthropolooical Archaeology 27:382-98.

Mora, R., I. de la Torre, and J. Martínez-Moreno. 2004. "Middle Palaeolithic mobility and land use in the southwestern Pyrenees: The example of Level 10 in La Roca dels Bous (Noguera, Catalunya, Northeast Spain)," in Settlement dynamics of the Middle Paleolithic and Middle Stone Age. Edited by N. Conard, pp. 415-35. Tübingen: Kerms Verlag.

Mora, R., J. Martínez-Moreno, and J. Casanova. 2008. Abordando la noción de "variabilidad musteriense" en Roca dels Bous (Prepirineo suroriental, Lleida). Trabaios de Prehistoria $65: 13-28$.

Mora, R., X. Terradas, J. Martínez, E. Pardos, and M. Pallarés. 1992. "Primera aproximación al estudio de las ocupaciones humanas de la Cueva de l'Estret de Tragó (Os de Balaguer, Lérida)," in Aragón/Litoral Mediterráneo. Edited by P. Utrilla, pp. 97-105. Zaragoza: Instituto Fernando el Católico.

Mourre, V. 2003. "Discoïde ou pas discoïde? Reflexions sur la pertinence des critères techniques définissant le débitage discoïde," in Discoid lithic technology: Advances and impli- 
cations. Edited by M. Peresani, pp. 1-18. BAR International Series 1120. Oxford: Archaeopress.

Mourre, V., and C. Thiébaut. 2008. L'industrie lithique du Moustérien final de la Grotte du Noisetier (Fréchet-Aure, Hautes-Pyrénées) dans le contexte des Pyrénées centrales françaises. Treballs d'Arqueologia 14:87-104.

Mussi, M. 2002. Earliest Italy: An overview of the Italian Paleolithic and Mesolithic. New York: Kluwer Academic/Plenum.

Parry, W. A., and R. L. Kelly. 1987. "Expedient technology and sedentism," in The organization of core technology. Edited by J. K. Johnson and C.A. Morrow, pp. 285-304. Boulder: Westview Press.

Pereira, T., J. Cascalheira, J. Marreiros, F. Almeida, and N. Bicho, N. 2012. Variación en la explotación de la cuarcita durante el Paleolítico superior en el Suroeste de la Península Ibérica. Trabaios de Prehistoria 69:232-56.

Plisson, H. 1985. Étude fonctionnelle d'outillages lithiques préhistoriques par l'analyse des microusures: Recherche méthodologique et archéologique. Thèse de $3^{\text {e }}$ cycle, Université de Paris I.

. 1986. Analyse des polis d'utilisation sur la quartzite. Early Man News 9/10/11:47-50.

Raposo, L., and J. L. Cardoso. 1998. Las industrias líticas de las Gruta Nova de Columbeira (Bombarral, Portugal) en el contexto del Musteriense final de la Península Ibérica. Trabajos de Prehistoria 55:39-62.

Rios-Garaizar, J. 2005. "Características de la producción lítica al final del Paleolítico Medio en el País Vasco: El caso del nivel B de Axlor (Dima, Bizkaia)," in Neandertales cantábricos: Estado de la cuestión. Edited by R. Montes and J. A. Lascheras, pp. 333-48. Monografías del Museo Nacional y Centro de Investigación de Altamira 20. Madrid: Ministerio de Cultura.

2010. Organización económica de las sociedades neandertales: El caso del nivel VII de Amalda (Zestoa, Gipuzkoa). Zephyrus LXV:15-37.

Rios-Garaizar, J., A. Eixea, and V. Villaverde. 2015a. Ramification of lithic production and the search of small tools in Iberian Peninsula Middle Paleolithic. Quaternary International 361:188-99.

Rios-Garaizar, J., D. Garate, A. Gómez, E. Iriarte, D. Arceredillo, et al. 2015b. Short-term Neandertal occupations in the late Middle Pleistocene of Arlanpe (Lemoa, northern Iberian Peninsula). Comptes Rendus Palevol. doi.org/10.1016/j.crpv.2014.11.006.

Rios-Garaizar, J., D. Garate, A. Gómez-Olivencia, E. Iriarte-Avilés, A. Aranburu-Artano, et al. 2011. The Lower to Middle Palaeolithic transition in northern Iberia: New data from Arlanpe Cave. Antiquity 85:329.

Roldán, C., J. Carballo, S. Murcia, Eixea, A., V. Villaverde, V. and J. Zilhão. 2015. Identification of local and allochthonous flint artefacts from the Middle Palaeolithical site "Abrigo de la Quebrada" (Chelva, Valencia, Spain) by macroscopic and physicochemical methods. X-Rav Spectrometry 44:209-16. doi10.1002/xrs.2602.

Sáenz de Buruaga, A. 1991. El conjunto industrial achelense del embalse de Urrunaga (Álava). Zephyrus XL/XLI: 27-54.

Santamaría, D. 2012. La transición del Paleolítico medio al superior en Asturias. El abrigo de La Viña (La Manzaneda, Oviedo) y El Sidrón (Borines, Piloña). PhD dissertation, Universidad de Oviedo. 
Serna, J. L. 1999. El Paleolitico medio en la provincia de Albacete. Instituto de Estudios Albacetenses "Don Juan Manuel," Albacete.

Silva, A., M. Otte, A. C. Araújo, N. Cauwe, J. M. Léotard, M. Lejeune, P. Lacroix, and F. Collin. 1991. A gruta do Escoural: Novas perspectivas para o seu estudo e valorização. Actas das IV Jornadas Arqueológicas. Lisboa: Associação dos Arqueólogos Portugueses, pp. 173-81.

Slimak, L. 1998-1999. La variabilité des débitages discoïdes au Paléolitique Moyen. Préhistoire Anthropologie Méditerranéennes 7-8:75-88.

. 2003. "Les débitages discoïdes moustériens: Évolution d'un concept technologique," in Discoid lithic technology: Advances and implications. Edited by M. Peresani, pp. 33-66. BAR International Series 1120. Oxford: Archaeopress.

Tavoso, A. 1987. Le Moustérien de la grotte Tournal. Cypsela VI:161-74.

Terradas, X. 2003. "Discoid flaking method: Conception and technological variability," in Discoid lithic technology: Advances and implications. Edited by M. Peresani, pp. 19-31. BAR International Series 1120. Oxford: Archaeopress.

Turq, A. 1989. "Exploitation des matières premières lithiques et occupation du sol: L'exemple du Moustérien entre Dordogne et Lot," in Variations des paléomilieux et peuplement préhistorique. Edited by H. Laville, pp. 179-204. Paris: CNRS.

—. 1992. "Raw material and technological studies of the Quina Mousterian in Perigord," in The Middle Paleolithic: Adaptation, behavior and variability. Edited by H. Dibble and P. Mellars, pp. 75-85. Philadelphia: University of Pennsylvania.

Turq, A., J. P. Faivre, P. Goldberg, S. McPherron and D. Sandgate. 2008. "Le Moustérien du Périgord Noir: Quoi de neuf?” in Les sociétés du Paléolithique dans un grand sud-ouest de la France: Nouveaux gisements, nouveaux résultats, nouvelles methods. Edited by J. Jaubert, J. G. Bordes, and I. Ortega, pp. 83-93. (Journées SPF, Université Bordeaux 1, Talence, 24-25 Novembre 2006). París: Société Préhistorique Française.

Tuffreau, A. 1987. Le Paléolithique inférieur et moyen du nord de la France (Nord, Pas-deCalais, Picardie) dans son cadre stratigraphique. Thèse de doctorat d'État de l'Université des Sciences et Techniques de Lille.

Utrilla, P. 1987. La cueva de Peña Miel: Nieva de Cameros, La Rioja. Madrid: Ministerio de Cultura.

Vallespí, E., A. Ciudad, and R. García. 1979. Achelense y Musteriense de Porzuna (Ciudad Real). Materiales de superficie I (colección E. Oliver). Estudios y Monografías 1. Museo de Ciudad Real.

1985. Achelense y Musteriense de Porzuna (Ciudad Real). Materiales de superficie II (muestra de las colecciones de A. Retamosa y M. Expósito). Universidad de Castilla-La Mancha. Ciudad Real.

Villaverde, V., A. Eixea, J. Rios, and J. Zilhão. 2012. Importancia y valoración de la producción microlevallois en los niveles II y III del Abrigo de la Quebrada (Chelva, Valencia). Zephyrus LXX:13-32.

Villaverde, V., A. Eixea, and J. Zilhão. 2008. Aproximación a la industria lítica del Abrigo de la Quebrada (Chelva, Valencia). Treballs d'Arqueologia 14:214-29.

Wallace, I. J., and J. J. Shea. 2006. Mobility patterns and core technologies in the Middle Paleolithic of the Levant. Lournal of Archaeological Science 33:1293-1309.

Yamada, M. 1996. "L'industrie lithique moustérienne aux Balzi Rossi (Ligurie, Italie)," in Proceedings of the XIII International Congress of Prehistoric and Protohistoric Sciences. Ed- 
ited by F. Facchini, A. Palma di Cesnola, M. Piperno, and C. Peretto, pp. 315-21. Forli: ABACO.

Zilhão, J., and V. Villaverde. 2008. The Middle Paleolithic of Murcia. Treballs d'Arqueologia 14:229-48.

Zilhão, J., D. Angelucci, Th. Aubry, E. Badal, J. P. Brugal, et al. 2013. "A Gruta da Oliveira (Torres Novas): Uma jazida de referência para o Paleolítico Médio da Península Ibérica," in Arqueologia em Portugal-150 Anos. Edited by J. M. Arnaud, A. Martins, and C. Neves, pp. 259-68. Lisboa: Associação dos Arqueólogos Portugueses. 